\title{
Covid-19 katastrofa: Nad knihou Richarda Hortona ${ }^{1}$
}

\author{
Daniel D. Novotný \\ Teologická fakulta \\ Jihočeská univerzita $v$ Českých Budějovicích \\ Kněžská 8, 37001 České Budějovice \\ novotnyd@jcu.cz
}

V této recenzní studii se zamýšlím nad knihou Richarda Hortona a jeho tezí, že západní země v odpovědi na současnou epidemii v první polovině roku 2020 až na výjimky selhaly. V pěti sekcích článku se po úvodní modifikaci Hortonovy teze (A) zabývám marginalizačním přístupem Číny (B), mitigačním přístupem Západu (C), epidemií SARS jako klíčové události v oblasti globálního veřejného zdraví (D), př́činami selhání Západu (epistemickými, politickými, etickými, kulturními atd.) (E), a v závěru i dalšś perspektivou (F).

Klíčová slova: etika epidemie, covid-19, veřejné zdraví, zdravotní politika, Západ

\section{A. Úvod}

Epidemie jsou jevem, který výrazně zasahuje do dějin lidstva od samých počátků. ${ }^{2}$ Je proto poměrně překvapivé, že se tomuto jevu filosofové

1 Za cenné komentáře k článku děkuji Dagmaře Dzúrové, Evě Fuchsové, Michalu Janatovi, Filipu Křepelkovi, Kamilu Sedláčkovi, Jakubovi Tomkovi a anonymním recenzentům časopisu Fillosofie dnes. Dále děkuji za podnětné diskuse k tématu článku Václavu Hořejšímu, Jaroslavu Flegrovi, Pavlu Ševčíkovi, Petru Svobodovi, Pavle Doležalové, Pavlu Vachtlovi a dalším členům Iniciativy Sníh (https://www.iniciativa-snih.cz/).

2 Termín,epidemie“ pochází etymologicky z řeckého غ̇đí „na“ a $\delta \tilde{\eta} \mu$ os „lid“; pojem je definován jako nadměrný výskyt nemoci v dané populaci (bud' vǔči nulovému či nějakému základnímu, běžnému výskytu endemickému). V lékařském kontextu je termín poprvé doložen u Hippokrata v jeho díle, významově doznal v průběhu dějin proměn, srv. Martin \& Martin-Granel (2006). V tomto širším smyslu se nemusí jednat jen o epidemie infekčních, ale i neinfekčních chorob (Green et al. 2002). K dějinám epidemií, srv. Snowden (2020) a Walter-Toews (2020). Většina nových infekčních epidemií má původ ve zvířecí říši, srv. Quammen (2012). 
doposud věnovali spíše okrajově. ${ }^{3}$ Současná pandemie covid-19 nicméně podněcuje nově i zájem filosofů, především etiků, a lze očekávat, že se mu budou nadále věnovat soustavněji, než tomu bylo doposud. ${ }^{4} \mathrm{~V}$ této recenzní studii bych rád k tomuto oživenému zájmu přispěl zamyšlením nad nevelkou, nicméně pozoruhodnou knihou Richarda Hortona, šéfredaktora prestižního lékařského časopisu The Lancet, s názvem The Covid-19 Catastrophe, která byla publikována v létě 2020.5 Třebaže se jedná o knihu, kterou nenapsal profesionální filosof, obsahuje řadu podnětů, které jsou relevantní i pro filosofy, především pro ty, které zajímají etické, sociálně-politické a sociálně-epistemické souvislosti

3 Zájem je především ze strany etiků: kolektivní monografie The Ethics of Pandemics (Schwartz 2020) je patrně první knihou, která systematicky pokrývá etická témata týkající se etiky epidemií, především s ohledem na covid-19: etika veřejného zdraví, profesní zodpovědnost, spolupráce veřejnosti, alokace vzácných zdrojů, spravedlnost, etika výzkumu, soukromí a sledování, otevření společnosti. O něco méně systematický je jinak souhrnný sborník Epidemics and Ethics, vydaný po epidemii SARS, srv. Balint et al. (2006). K některým dalším etickým tématům (bezpečnost, lidská práva, demokracie atd.) se vyjadřuje i český sborník Vítězové a poražení: Právní a etické problémy současné koronakrize (Šejvl et al. 2020). Dalším významným informačním zdrojem jsou webové stránky Epidemic Ethics (https://epidemicethics.tghn.org/), které spravuje WHO ve spolupráci s dalšími organizacemi. Jedná se o platformu pro prakticky orientované bioetiky a další zájemce o multidisciplinární tematiku veřejného zdraví. Etická témata jsou ad hoc probíraná i v učebnicích epidemiologie, ovšem doposud jsem nezaregistroval, že by se tak dělo systematicky, srv. např. Rothman et al. (2008). Obsáhle se současné epidemii věnuje i speciální číslo Journal of Bioethical Inquiry (17 (4), December 2020, Symposium Title: Social and Ethical Implications of the COVID-19 Pandemic). Obecně vzato je nicméně téma infekčních chorob v bioetice relativně opomíjené. Srv. jednu z mála podrobnějších studií: The Patient as Victim and Vector: Ethics and Infectious Disease (Battin et al. 2009).

O epidemiologii a epidemie se kromě etiků zajímají i odborníci na další filosofické poddisciplíny, především epistemologové: zde se dokonce objevily pokusy o uvedení filosofie epidemie jako speciální poddisciplíny, a to v knize Philosophy of Epidemiology (Broadbent 2013). Autor se zabývá tématy, jako je kauzalita, explanace, predikce, riziko, evidence (a užití v právu), metodická pluralita, atd. Pozoruhodná diskuse k epistemologii epidemiologie se rozvinula mezi stanfordským klinickým epidemiologem Johnem Ioannidisem a harvardským infekčním epidemiologem Markem Lipsitchem a dalšími. Skvělé shrnutí diskuse poskytuje filosof medicíny z Pittsburgu Jonathan Fuller (2020). Užitečné poznámky k Ioannidisově problematickému pojetí epidemie covidu-19, srv. též Kulveit (2021). Filosofické a teologické postřehy kulturního rázu poskytují např. knihy Žižek (2020) či Lennox (2020).

4 Rostoucí bibliografii k tématu filosofie covidu-19 lze nalézt v Delvaux \& Rajan (2020).

5 Richard Horton (nar. 1961) vystudoval medicínu na Univerzitě v Birminghamu. Jako šéfredaktor časopisu The Lancet pracuje od roku 1995. Je čestným profesorem prestižních institucí jako je London School of Hygiene and Tropical Medicine, University College London, či Univerzita v Oslo. Kromě řady odborných článků přispívá i do periodik jako jsou The Times Literary Supplement a The New York Review of Books. Tématům, která jsou blízká filosofii, především etickým, sociálně epistemologickým a sociopolitickým aspektům zdravotnictví, se Horton věnuje dlouhodobě, mimo jiné i ve své knize o kontroverzích v moderní medicíně Second Opinion: Doctors, Diseases and Decisions in Modern Medicine (Horton 2003). 
krize zpo̊sobené současnou pandemií (tzv. koronakrize). Na řadě míst se autor inspiruje pracemi některých současných filosofů, naopak čistě lékařským a epidemiologickým aspektům covidu-19 se Horton téměř nevěnuje. ${ }^{6}$

Hortonova centrální teze a východisko úvah bude patrně pro některé české čtenáře provokativní7: západní svět již během prvního půl roku, tedy v době publikace knihy, selhal v odpovědi na novou epidemii, přičemž př́ičiny tohoto selhání nejsou primárně vnější, zpưsobené nějakou zahraniční vládou (nap̌̌. ČLR, Čínskou lidovou republikou) nebo mezinárodní institucí (např. WHO, Světovou zdravotnickou organizací), ale vnitřní. Horton svou tezi formuluje takto:
„Odpověd' vlád na covid-19 představuje největší politické selhání západních demokracií od druhé světové války. První odpovědností vlády je její povinnost pečovat o občany. Prvotní nečinnost vlád vedla $\mathrm{k}$ tisícům zbytečných úmrtí, kterým bylo možné se vyhnout.“8

Otázky, které si Horton klade, zní, proč k tomuto došlo a jak případně podobnému selhání zabránit v budoucnosti. V této recenzní studii bych se rád spolu s Hortonem nad tezí o selhání Západu a jeho přícinách zamyslel.

6 Z knih, které poskytují základní systematický přehled současného medicínského poznání SARSCoV-2 s odkazy na další odborné časopisecké publikace, lze doporučit Rabadán (2020). Hlubší analýzu podává sociobiolog Nicholas Christakis (2020), působící na Yaleově univerzitě. V češtině čtivým způsobem shrnul základní informace o koronaviru Koubský (2020), který se ovšem naneštěstí některým základním otázkám nevěnuje, především rozdílu mezi mitigací a marginalizací (vysvětleno dále). Dzúrová \& Jarolímek (2020) v březnu publikovali jeden z prvních kvalitních odborných článků o epidemii nového koronaviru v češtině. Pro podrobné zhodnocení z hlediska právního, srv. Křepelka (2020).

7 Např́klad pro ty, kteří nejenže nepovažují nový koronavirus za hrozbu, kterou Západ podcenil, ale naopak za falešný poplach, na který Západ reagoval příliš razantně. Těm, kteří hrozbu nového koronaviru považují za přeceňovanou, se v Česku přezdívá „chřipečkáři“ pro jejich tendenci považovat zdravotní rizika nového koronaviru za srovnatelné s chřipkou, a tedy neopravňující k výraznějším nefarmakologickým intervencím, jako jsou plošné uzávěry či povinnost nosit roušky (srv. např. Holub 2020). Horton nijak přímo na toto stanovisko nereaguje, v zahraničí má mezi relevantními odborníky mizivou podporu, jak dokládá např. The John Snow Memorandum shrnující vědecký konsenzus (Černý et al. 2020).

8 „The response of governments to COVID-19 represents the greatest political failure of Western democracies since the Second World War. A government's first reponsibility is its duty to care to citizens. Early government inaction led to the avoidable deaths of thousands of those citizens.“ Horton (2020, s. 84). 
S Hortonovou tezí, v modifikované podobě uvedené níže, se ztotožňuji. Tuto studii lze tedy považovat za její zčásti samostatně postupující obhajobu. Výklad i argumentaci totiž budu strukturovat jinak než Horton, i vzhledem k tomu, že Hortonova kniha je místy nesystematická, argumentace zkratkovitá a terminologicky rozkolísaná, ke stejným otázkám se např. vyjadřuje vícekrát, dokonce i hlavní teze knihy je dle mého nejvýstižněji formulována až v páté kapitole. Poukážu dále na některé problematické aspekty Hortonovy argumentace, doplním mezery v jeho argumentaci a místy zavedu i pojmové distinkce, které Horton užívá jen implicitně. V rozsáhlém poznámkovém aparátu uvedu i odkazy na další literaturu k jednotlivým otázkám. Kategorizuji taktéž Hortonovy nesoustavné poznámky k příčinám selhání Západu, poukážu na některé meze jeho úvah týkající se tohoto tématu a identifikuji otázky, které zaslouží hlubšího zkoumání i do budoucna.

Článek je členěn takto: Nejprve, ve zbytku této úvodní sekce, bych rád pojmově precizoval Hortonovu tezi o selhání Západu, dále poukázal na metodické omezení tohoto článku, objasnil jeho motivaci a poskytl stručný informativní přehled obsahu Hortonovy knihy (A). Ve druhé části si stručně popíšeme a zhodnotíme rozdíly $\mathrm{v}$ přístupech $\mathrm{k}$ řešení epidemie v Číně (B) a následně především na Západě $(\mathrm{C})$, což poslouží jako obhajoba hlavní teze. K tématu příčin selhání Západu se váže sekce o zkušenosti s epidemií SARS (D), kterou ovšem za hlavní vysvětlení úspěchu či selhání, na rozdíl Hortona, nepovažuji. Ostatní příčiny a faktory selhání, které Horton uvádí, rozdělím na epistemické, politické a etické, a stručně je představím a navrhnu doplnění o faktory kulturní v sekci (E). Závěr je věnován výhledu na další zkoumání (F). ${ }^{9}$

Přejděme tedy nejprve k precizaci Hortonovy teze o selhání Západu. $\mathrm{K}$ tomuto bych rád připomenul dvojí. Zaprvé, že terminologicky budu rozlišovat mezi dvěma základními, fundamentálně odlišnými strategiemi řešení epidemie, dle cílo̊, které tato řešení sledují. Horton sám tuto terminologii neužívá, i když ji pojmově předpokládá: (1) radikální marginalizace či eliminace (supression) je strategie, jež cílí na zastavení či maximální omezení šíření viru populací; (2) mitigace (mitigation, flatten the curve) je strategie, jež cílí na pouhé zpomalení průchodu

9 V článku budu citovat z Hortonovy knihy in extenso, nebot’ v mnoha případech znějí Hortonova tvrzení týkající se veřejného zdraví a zdravotní politiky Západu poměrně radikálně a nechci je tedy opírat pouze o svou autoritu, ale o autoritu zkušeného šéfredaktora prestižního lékařského časopisu. 
infekce populací, nikoli na zastavení či minimalizaci šíření. ${ }^{10}$ Druhá strategie vede $\mathrm{k}$ výrazně vyšším ztrátám na zdraví a životech populace a nezdá se dle dostupných studií nikterak ekonomicky výhodná, ba právě naopak. ${ }^{11}$ Její zastánci např. poukazují na to, že úkolem společnosti není zachraňovat obyvatele před infekčními chorobami, ale pouze ochránit zdravotní systém před kolapsem. Jiní argumentují tím, že necháme-li projít vir populací, dosáhneme dříve přirozené skupinové imunity (herd immunity), a nebudeme se tak muset spoléhat na vakcíny a zasahovat do běžného životního stylu. S použitím této terminologie můžeme tezi článku formulovat tak, že mitigační strategie Západu selhala, zatímco eliminační strategie Číny uspěla.

Za druhé bych rád modifikoval Hortonovu tezi tím, že posunu definici „Č́ny“ a „Západu“ oproti jeho pojetí.12 Kdykoli Horton mluví o Západu, má na mysli paradigmaticky především Británii a USA, a kdykoli mluví o Číně, má na mysli především Čínskou lidovou republiku. Tento úzus může u některých povrchnějších čtenářů vyvolat klamný dojem, že selhávající přístup Západu je nějak vázán na liberálně demokratický režim, zatímco úspěšný přístup Číny na režim autoritářský. Od počátku epidemie se ovšem ukazuje, že v odpovědi na epidemii je vhodné vést řez nikoli po linii „západní liberální demokracie vs. autoritářský režim

10 Anglická i česká terminologie je rozkolísaná, především i v souvislosti s velkým multioborovým zájmem o pandemii covid-19. Pro vyjasnění terminologie běžně užívané odborníky na infekční choroby před příchodem covid-19, viz Dowdle (1998). Dle Dowdleho znamená „eliminace“ lokální snížení patogenu na nulovou či mizivou hodnotu, s rizikem importu, zatímco „eradikace“ jeho trvalé globální odstranění z populace. V tomto významu i např. Philips (2021) v diskusi o tom, zda lze covid-19 eliminovat či nikoli. Jiní autoři ovšem neváhají mluvit o „lokální eradikaci“ a „globální eradikaci“ (Wayne \& Bolker 2015, s. 21). Během pandemie byla do angličtiny zaváděna i řada nových termínů např. „flatten the curve“ („zploštit křivku“), ,zero COVID“ či „containment“ (např. Priesemann et al. 2020). Podobně i v češtině je termín „marginalizace“ nový ve významu zde užívaném, tj. minimalizace až eliminace přenosu patogenu v populaci. Přebírám jej od René Levínského a Pavla Hroboně, kteří jej zavedli na jaře 2020 (ústní komunikace).

11 Viz webové stránky Our World in Data (https://ourworldindata.org/covid-health-economy). Potvrzují se tak studie z předchozích epidemií, z nichž je patrné, že ochrana zdraví je zároveň i tou nejlepší ochranou ekonomiky. Podobné stanovisko hájí i australský ekonom Joshua Gans (2020). Pro období ekonomické výhody marginalizační strategie v období španělské chřipky srv. např. studii Correia et al (2020). Na námitku, že nelze srovnávat epidemii španělské chřipky s epidemií covid-19 a vyvozovat z tohoto srovnání nějaké závěry, lze doporučit jakýkoli úvod do studia epidemií a dalších fenoménů tzv. „závislých událostí“, např. vynikající Kucharski (2020).

12 Horton nikde nevymezuje pojem Západu, lze se ale z kontextu domnívat, že se pravděpodobně kryje s civilizačním okruhem vymezeným např. Samuelem Huntingtonem (2001), tj. USA, Kanada, tradiční katolické a protestantské části Evropy, Austrálie a Nový Zéland. Hlavní pozornost ovšem Horton věnuje Británii. Zmínka Huntingtonova dělení má v tomto článku čistě heuristický charakter a nijak nenaznačuje můj souhlas s tezemi autora. 
ČLR“, ale právě po výše zmíněné linii „mitigační přístup většiny zemí západního civilizačního okruhu“ a „eliminační přístup východních zemí čínského a budhistického civilizačního okruhu“. Důležité je tedy hned na počátku této studie zdo̊raznit fakt, že východní země zahrnují nejen autoritářské režimy jako je ČLR, ale i plné demokracie jako je Tchajwan. Navíc existují i západní země s marginalizační/eliminační strategií jako je Austrálie a Nový Zéland. ${ }^{13}$

Nyní k metodickým omezením této recenzní studie a jejich důvodům. Za prvé chronologické omezení: podobně jako Horton ve své knize publikované uprostřed léta 2020, se omezím na epidemickou situaci v první polovině roku 2020. Považuji za zásadní prokázat fakt, že Západ selhával při řešení epidemie již v tomto období první vlny, jakkoli daleko zřetelněji se v mnoha (nikoli ve všech) západních zemích projevilo selhání i v druhé polovině roku 2020, při nástupu druhé a v některých zemích dokonce i třetí vlny. ${ }^{14}$ Neschopnost dostatečně chránit veřejné zdraví v druhé polovině 2020 je přitom zřejmější, zároveň ale daleko méně pochopitelná a ospravedlnitelná, nebot’ poznání epidemie a metod jejího řešení se zásadně prohloubilo z hlediska přesnosti i míry jistoty. Toto se týká jak „známých rizik neznámého“ (dlouhodobé následky, reinfekce, mutace), tak „efektivity známého, ale jen provizorně podloženého“ např. globálními zkušenostmi a předběžnými studiemi (roušky, distancování, trasování, lockdowny a další nefarmakologické intervence). Dle Hortona i dle mého vlastního přesvědčení bylo selhávání Západu zřejmé již od počátku, prospektivně, a nikoli pouze nyní, retrospektivně. ${ }^{15}$

13 Horton sám tedy toto dělení neužívá a k zemím z ostatních civilizačních okruhů se příliš nevyjadřuje. Zdá se, že i u ostatních civilizačních okruhů by mohla existovat korelace s volbou mitigační či eliminační/marginalizační strategie: země pravoslavného, latinskoamerického a islámského civilizačního okruhu volí mitigaci, zatímco země subsaharského okruhu radikální marginalizaci. Hinduistické země (Indie, Nepál) se pokoušely od počátku spíše o marginalizaci, ovšem na rozdíl od čínských a budhistických zemí se smíšeným úspěchem. Systematické komparativní zkoumání pro jednotlivé země a kulturní okruhy by navíc muselo vzít v úvahu to, že docházelo ke změnám strategií. (Např. Česko na první vlnu reagovalo jako by cílem bylo epidemii marginalizovat, následně ovšem zvolilo mitigaci).

14 Pojem „vlna“ je vágní, v intuitivním smyslu znamená ohraničenou zvýšenou incidenci infekce či jiné relevantní veličiny, kterou lze v určitém období zřetelně sledovat, např. i vizuálně při pohledu na grafické znázornění. (Které ovšem závisí na zvoleném měřítku, navíc postupem času se např. nějaká vlna může stát téměř mizivou ve srovnání s jinou, větší, či se ukáže, že na ni lze hledět i jen jako na vlnku na jiné větší vlně).

15 Toto dokládají i mé odhady vývoje, publikované v rozhovoru v polovině března 2020 (Kerles 2020a), poukazující na dramatické rozdíly v přístupech západních a asijských zemí, a z července 2020, poukazující na vytvoření „druhé vlny“ (Kerles 2020b). 
Za druhé bych rád z hlediska metodologie poukázal na to, že při studiu našeho tématu by bylo možné postupovat nejen deskriptivně a argumentativně, ale i kvantitativně, např. analýzou statistik úmrtnosti, tj. kumulativních počtů evidovaných covid úmrtí v přepočtu na obyvatele, a to navíc i v globální komparaci pro jednotlivé země či s korelacemi na další parametry, např. ekonomické. ${ }^{16}$ Horton toto nečiní: kvantitativní údaje, které příležitostně uvádí, jsou ilustrativní a nejsou podrobeny hlubším komentářom. Podobně tedy budu postupovat i v této studii, a to především z praktických důvodů, nebot’ přínosný rozbor kvantitativních údajů byvyžadovaljinou studii sjinou metodologií.Zdejen konstatuji,žedle jakkoli zvolených kvantitativních měřítek, zásadní rozdíly v míře úspěchu mezi zeměmi marginalizačními (např. Vietnam či Thajsko) a mitigačními (např. Česko či Belgie) zůstává po celý rok 2020. V úmrtnosti dokonce bylo dosaženo až neuvěřitelných trojciferných řádových rozdílů. ${ }^{17}$

Někteří mohou Hortonovu tezi o selhání západních zemí během současné koronakrize považovat apriorně za dezinformaci. ${ }^{18}$ Důležité je proto porozumět základní Hortonově motivaci k sepsání knihy, jež spočívá v apelu na to, abychom se do budoucna vyhnuli zbytečným ztrátám na životech i zde na Západě a reformovali své jinak kvalitní vědecké a další liberálně demokratické instituce. Kritická sebereflexe

16 Skvělé globální statistiky poskytuje především Our World in Data (https://ourworldindata.org/ coronavirus). Agregované globální statistiky k novému koronaviru se objevily nejprve na dobrovolnickém anonymním webu Worldometer (https://www.worldometers.info/).

17 Jakkoli v tomto článku neprezentuji kvantitativní aspekty epidemie, je třeba jejich alespoň elementárního předporozumění, které lze získat studiem statistik a znalostí kontextu. Někdo by např. mohl tvrdit, že na vyhodnocení úspěšnosti nějaké strategie je př́liš brzy a že západní země, které se během první vlny „promořily“, tj. podstatná část jejich populace bud’ zemřela, či získala přirozenou imunitu, již nebudou muset čelit významné druhé vlně. A to na rozdíl od dálněvýchodních zemí, které teprve nyní zasahuje druhá vlna, která rozdíly se západními zeměmi „srovná“. Třebaže přirozená imunizace je faktorem pro rychlost šiření epidemie, ukazuje se, že ještě i na jaře 2021 (poslední revize textu tohoto článku) jsou rozdíly v druhých vlnách v západních a dálněvýchodních zemích po kvantitativní stránce dramaticky odlišné. Jinými slovy, dálněvýchodní země, které byly ochotny a schopny epidemii od počátku marginalizovat/eliminovat, měly i při druhé vlně jen mizivé počty nakažených i úmrtí, a to na rozdíl od zemí západních (např. stomiliónový Vietnam evidoval 34 úmrtí, sedmdesátimiliónové Thajsko několik osob; Tchajwan druhou vlnu neměl vůbec).

18 Např. tvrzení „EU není schopná na danou krizi efektivně reagovat“ je označeno za dezinformaci na stránkách Ministerstva vnitra ČR. (Srv: MV ČR (2021): „Koronavirus: Přehled hlavních dezinformačních sdělení. “In Ministerstvo vnitra České republiky [online]. C)2021. Dostupný z: https://www.mvcr.cz/cthh/clanek/koronavirus-prehled-hlavnich-dezinformacnich-sdeleni. aspx.) V uvedeném kontextu na stránkách ministerstva lze s tímto hodnocením patrně souhlasit, problémem se ale stává rutinní snaha označovat za dezinformaci jakoukoli kritiku poukazující na selhávání EU, Česka či jiných západních zemí a institucí. 
je prvním krokem správným směrem. Naopak popření problému či manipulace $\mathrm{s}$ fakty za tím účelem, abychom populisticky vytvořili zdání úspěchu a zakryli selhání jednotlivců i institucí, nás v budoucnu $\mathrm{s}$ vysokou pravděpodobností opět povede k obrovským zbytečným ztrátám zdravotním, hospodářským, morálním, kulturním, sportovním, vzdělanostním, a jiným. ${ }^{19}$

Hortonova kniha je rozdělena do sedmi kapitol. ${ }^{20} \mathrm{~V}$ první kapitole Horton stručně charakterizuje vlastnosti viru (index nakažlivosti, smrtnost atd.), připomíná základní chronologii událostí pro Čínu i některé západní země a podává přehled o stavu epidemie k 25. květnu (celosvětově bylo tehdy evidováno téměř 330 ooo úmrtí). V druhé kapitole se autor věnuje tématům, jako je špatná připravenost Británie na pandemii a rozhodnutí USA ukončit spolupráci s WHO, virus SARS, otázka zodpovědnosti Číny za průběh pandemie v západních zemích, a tzv. infodemie. Ve třetí kapitole Horton rozebírá úspěchy vědy během současné epidemie a paradoxně zároveň obrovské selhání vědecké politiky. Čtvrtá kapitola se krátce a nepř́liš systematicky věnuje postupu různých zemí během epidemie, zmiňuje mj. solidaritu a společnou akci jako základ služby veřejného zdravotnictví. Obzvláště zajímavá je pátá kapitola o politice covidu-19. Zde se nachází ona výše citovaná formulace Hortonovy teze, že odpověd’ západních vlád na covid-19 představuje největši selhání od druhé světové války. Selhání byla mnohá, Horton vypočítává některá $\mathrm{z}$ nich. V šesté kapitole se Horton vyjadřuje $\mathrm{k}$ roli vědy $\mathrm{v}$ (západní) společnosti, k hodnocení rizik, problému svobody a sledování, a obecně ke společenským otázkám. V závěrečné kapitole autor vypočítává změny, které současná krize dle jeho názoru přinese či by měla přinést (poukazuje např. na to, že covid-19 naneštěstí mezinárodní společenství spíše rozdělil, než spojil, očekává posílení i reformu WHO).

19 Horton dle mého zcela správně vidí v současné koronakrizi známky existenčního ohrožení západních demokracií: „... deficiencies in decision-making [that] reflect not only the surprising fragility of modern science-based societies but also something far worse - inherent failures in the mechanics of Western democracies that threaten their very existence." Horton (2020, s. 40). Důležité je zde upozornit, že se nejedná o ohrožení demokracií jako takových, nebot’ robustní asijské demokracie (Tchajwan, Korea, Japonsko, atd.) umí epidemii řešit velmi efektivně marginalizací či dokonce eliminací.

20 Pro úplnost zde uvádím názvy jednotlivých kapitol: 1 . Z Wu-chanu do světa (From Wuhan to the World), 2. Proč jsme nebyli připraveni? (Why Were We Not Prepared?), 3. Věda: paradox úspěchu a selhání (Science: The Paradox of Success and Failure), 4. První linie obrany (First Line of Defence), 5. Politika covidu-19 (The Politics of COVID-19), 6. Nové posouzení společnosti rizik (The Risk Society Revisited), 7. Na cestě k další pandemii (Towards the Next Pandemic). 


\section{B. Čína}

Původ epidemie v Číně je téma, které budí pozornost odborníků i veřejnosti. Má svi̊j teoretický i bezpečnostní rozměr. Poměrně záhy od vypuknutí epidemie dospěla drtivá většina odborníků $\mathrm{k}$ závěru, že původ SARS-CoV-2 lze vysvětlit zoonózou, tedy přenosem na člověka ze zviŕrete, vzhledem $\mathrm{k}$ vysoké podobnosti, kterou tento vir vykazuje s některými netopýř́mi viry. Řada odborníků dokonce již po dvě desítky let poukazovala na vysokou pravděpodobnost této události $\mathrm{v}$ daném regionu Č́ny a jihovýchodní Asie. ${ }^{21}$ Ovšem vzhledem k tomu, že z podstaty věci není snadné zjistit, kdy přesně a jak $\mathrm{k}$ zoonóze došlo, vzniklo záhy i podezření, zda nebyl v př́rodě vzniklý vir zkoumán či dokonce uměle modifikován v mezinárodní virologické laboratoři ve Wu-chanu (WIV), odkud navzdory tomu, že má nejvyšší bezpečnostní certifikaci BLS4, nějakou neštastnou náhodou unikl. ${ }^{22}$ Třebaže se nezdá být možné s absolutní jistotou vyloučit domněnky o nehodě, mezi relevantními odborníky mají mizivou podporu (jakkoli plánované a probíhající komise organizované WHO a The Lancet zkoumají i tuto možnost). Navíc, i když je otázka původu epidemie zajímavá, odpověd’ na ni není relevantní z hlediska hodnocení Hortonovy teze, je tedy pochopitelné, že se jí náš autor téměř nevěnuje. ${ }^{23}$

Další zajímavou, ovšem obtížnou a pro hlavní tezi tohoto článku nepř́lišs relevantní otázkou, je rekonstrukce rané fáze š́řrení epidemie v ČLR koncem roku 2019. I zde je třeba v mnohém čekat na další šetření a výzkum. Známe přinejmenším základní chronologický rámec pro konec prosince a pro leden: „30. prosince 2019,“ píše Horton, „byly odebrány vzorky pacientovi trpícímu na neznámý typ zápalu plic. Byl

21 Odborníci jako Peter Daszak či Shi Zhengli, kteří se mnoho let zabývají netopýŕím viromem, dlouhodobě poukazují na velkou pravděpodobnost vzniku nových infekčních nemocí typu SARS, vzhledem k obrovské virové biodiverzitě v regionu a ekologickým změnám, které doposud izolovanější živočišné druhy přivádí do blízkých kontaktů s lidmi. Srv. nap̌r. Latinne et al. (2020).

22 Srv. Cyranoski (2020). Jakkoli je známa řada nehod v biologických laboratořích po celém světě, veškeré doposud vzniklé epidemie vznikly přirozeným způsobem: apriorní pravděpodobnost vzniku další epidemie přirozeným přenosem je tedy daleko vyšší než pravděpodobnost vzniku nehodou. Je důležité nezaměňovat dvě zcela odlišné otázky totiž (a) Jaká je pravděpodobnost vzniku pandemie covid-19 únikem viru z WIV? (b) Jaká je pravděpodobnost, že ČLR potvrdí vznik pandemie covid-19 v př́padě, že skutečně vznikl únikem z WIV? Otázky biologických rizik přirozených i umělých, v kontextu obecného pojednání o existenčních rizicích, stručně pojednává Toby Ord. Srv. Ord (2020).

23 Nejnověji ke stavu mezinárodního zkoumání, srv. Mallapaty et al. (2021). 
přijat do nemocnice Jin Yin-tan ve Wu-chanu, v čínské provincii Hubei. Test reverzní transkripční polymerázové řetězové reakce (RT-PCR) potvrdil př́itomnost nového typu koronaviru." ${ }^{24} \mathrm{Na}$ nebezpečí nemoci, později nazvané ,covid-19', kterou tento nový koronavirus způsobuje, mnozí čínští lékaři upozorňovali své kolegy i místní úřady. Zmiňován je především Li Wen-liang, oftalmolog, který na covid-19 zemřel a je dnes považován v ČLR za hrdinu, jemuž bylo na místní policejní stanici pod nátlakem uloženo, aby ohledně nové nemoci „nešíŕil poplašnou zprávu“. Informace od provinčních lékařů, jako byl Li, se nicméně přesto dostaly k centrálním zdravotnickým autoritám v Pekingu. Ty kontaktovaly 31. prosince WHO, které následující den ustanovilo vyšetřující komisi. 3. ledna bylo již zaznamenáno 44 prŕípadů nové nemoci. Zdráhání ovšem nastalo s potvrzením, že dochází $\mathrm{k}$ přenosu z člověka na člověka (mnozí setrvávali u domněnky, že nákaza se přenáší jen z nakažených zviŕrat). ${ }^{25}$ Během ledna byl genotyp nového viru plně sekvenován týmem z univerzity Fu-tan v Šanghaji, v jehož čele stál Čang Jung-Čen, přičemž bylo zjištěno, že se jedná o vir př́buzný SARS, jednomu ze sedmi známých koronavirů, který napadá člověka. Kompletní výsledky byly zveřejněny 12. ledna. Následující den zaregistrovalo Thajsko, jako první země mimo ČLR, svi̊j první př́pad. 21. ledna první případ zachytilo USA. 23. ledna byla vyhlášena plošná karanténa ve Wu-chanu. 24. ledna začíná WHO zvažovat vyhlášení mimořádného PHEIC (Public Health Emergency of International Concern), tj. nejzávažnějšího upozornění, které WHO může vydat. ${ }^{26}$ Časopis The Lancet tohoto dne taktéž publikuje několik zásadních studií s informacemi o nové nemoci (srv. odkazy níže). Horton a mnozí další experti doporučují PHEIC vyhlásit, což se 30. ledna děje.

Po počátečním váhání došlo vČLR někdy v druhé poloviněledna kjasné volbě radikální marginalizační/eliminační strategie. Jednalo se ovšem o mimořádně náročnou intervenci a s propuknutím nákazy zápasilo ČLR i během února. ${ }^{27} \mathrm{~K}$ čínské protiepidemické odpovědi cituje Horton zprávu WHO týmu, který ve dnech 16. až 24. února navštívil ČLR. ${ }^{28}$

\section{Horton (2020, s. 1).}

25 Podrobněji k historii prvních lednových dní, s nejnovějšími informacemi z čínských i amerických zdrojů, srv. Bucley et al. (2020). Srv. též Christakis (2020).

26 To se vydává v případě, kdy jsou splněny dvě podmínky: (1) nemoc ohrožuje veřejné zdraví tím, že se šírí na mezinárodní úrovni; (2) nemoc vyžaduje mezinárodní koordinaci při svém řešení.

27 Horton např́iklad vyzdvihuje stavbu polních nemocnic (s. 67) a odkazuje na Simiao Chen et al. (2020).

28 WHO (2020). 
„Tváří v tvář dříve neznámému viru rozvinula Čína snad historicky nejambicióznější, nejagilnější a nejagresivnější úsilí omezit šíření nemoci v historii ... Dosažení výjimečného sjednocení Číny v dodržování těchto omezujících opatření bylo možné jen díky hlubokému odhodlání obyvatel Číny ke kolektivní akci tváří v tvář tomuto společnému ohrožení ... Odvážný čínský přístup k omezení rychlého šíření tohoto nového respiračního patogenu změnil směr rychle se stupňující a smrtící epidemie. “29

Zpráva mezinárodního týmu WHO byla pozitivní. Podobně dosvědčuje mimořádně kvalitní a obětavou práci při marginalizaci viru i Horton, především co se týče spolupráce čínských odborníků, zdravotníků a obyvatelstva. ${ }^{30}$ Tyto úspěchy stojí v kontrastu s neúspěchy ČLR během epidemie SARS-CoV-2 (jak uvidíme i dále). ${ }^{31}$

Znamená to, že postup ČLR byl od samého počátku ideální, jako se jeví např. postup Tchajwanu a dalších zemí v regionu? To rozhodně nikoli. Dokonce není vyloučena ani možnost, že rychlejší a razantnější počáteční reakce úřadů ČLR mohla zcela zabránit rozšśření epidemie do světa. ${ }^{32}$ Každopádně je třeba vzít v úvahu, jak obtížné je hodnotit míru rizika na samém počátku epidemie, dokud se „nic moc“ neděje, a zvážit i cenu za falešný poplach a potenciální paniku, která hrozí. V některých zemích ještě mnoho měsíců od počátku epidemie existovali lékaři,

29 Tamtéž.

30 „Central to this success was the series of major emergency research program on virus genomics, antivirals, traditional Chinese medicines, clinical trials, vaccines, diagnostics and animal models. China's commitment to rapidly acquiring knowledge about this new virus was a critical factor in enabling the country to contain, suppress and eventually extinguish the epidemic." Horton (2020, s. 45).

31 "The contrast between this impressive response and Chinese pitiful efforts during SARS in 2002-3 illustrates the remarkable scientific renaissance that had taken place in the country in just two decades. Bin Cao's team wasn't only able to gather the state of the art data on these early patients but also encouraged to write up their work, publish it free from censorship in foreign English-language medical journals, and make their findings available to others - all within weeks of the fire reports of the new disease. The culture, as well as the scientific shift that had taken place in China was monumental." Horton (2020, s. 42-43).

32 Jedná se o otázku, kterou není snadné zodpovědět. Srv. skvělý úvod od autorky, která biomedicínskou tematiku sleduje mnoho desítek let MacKenzie (2020). Obecně skeptický přístup k možnostem včasného vyhodnocení potenciálních pandemií vyjadřuje Honigsbaum (2020), na případových studiích deseti nemocí z posledního století. 
novináři a politici, kteř́ ničivost nového viru bagatelizovali a volali po promořovacím laissez faire prrístupu. Problematický postup úřadů ČLR v počátcích epidemie by tedy neměl vést ke snižování mimořádné obětavosti čínských lékařo i obyvatelstva, kterou projevili při důsledné aplikaci eliminační strategie od konce ledna:

„Čínská vláda dluží světu podrobnější vysvětlení toho, co se stalo ve Wu-chanu. ... prostě chci vědět, co se stalo. Něco se stalo. Musíme to vědět, abychom měli maximální šanci zabránit tomu, aby se to opakovalo. (...) Ale také - věřím, že to můžeme říci - si čínští vědci a zdravotníci zaslouží naši úctu. Osobně jsem poznal tyto oddané jednotlivce a vím, že neúnavně pracovali na tom, aby pochopili podstatu této pandemie. Považovali za svou povinnost informovat WHO, když si byli jisti, že je důvod signalizovat globální poplach. A při svých jednáních s čínskými vědci a veřejnými činiteli jsem nepozoroval nic jiného než mimořádné odhodlání otevřeně a bezpodmínečně spolupracovat s cílem porazit tuto nemoc.“ 33

Za zdůraznění zde patrně ještě jednou stojí i skutečnost, že je svým způsobem irelevantní, zda se ČLR umí s epidemií efektivně vyrovnat a poskytuje tedy pravdivé informace, či nikoli a poskytuje informace nepravdivé. Řada dalších zemí či samosprávných území v regionu, některé i s demokratickými či polodemokratickými režimy (např. Macao, Hongkong, Tchaj-wan, Jižní Korea, Thajsko, Singapur apod.), totiž epidemii bez pochybností marginalizovala či eliminovala v první polovině roku 2020 mimořádně efektivně, čímž tyto země ukázaly, že úspěšné intervence ve prospěch veřejného zdraví nejsou vázány na nějaký typ politického režimu. ${ }^{34}$

33 Horton (2020, s. 22). Zajímavá svědectví a reflexe tématu poskytuje Miller (2020), editor sborníku americko-čínské univerzitní iniciativy Duke University ve spolupráci s Wuhan University.

34 Horton sám se k postupu asijských zemí a území mimo ČLR vyjadřuje jen krátce, některé úspěšné země, jako je Vietnam či Thajsko, nezmiňuje vůbec. Jedná se o jistou slabinu Hortonovy knihy, třebaže pochopitelnou vzhledem k jejímu hlavnímu zaměření (selhání Západu, nikoli globální komparace). Spolu s Hortonem mluvím v této studii neutrálně až relativně pozitivně o Číně a opomíjím specifika Tchajwanu. Rád bych jen zdůraznil to, že epidemickou resilienci Tchajwanu považuji za naprosto exemplární, kromě její mimořádné efektivity (celková úmrt- 
Mimo ČLR bylo v době vyhlášení PHEIC koncem ledna zachyceno asi sto sedmdesát nakažených. Svět byl varován a veškeré základní informace o nové nemoci včetně nejčastějšího způsobu jejího přenosu byly známy a poskytnuty světu během ledna. Ve světle dalších šetření se může ukázat, že ČLR zdrželo informace o nové epidemii déle, než je doposud známo. Základním faktem ale zůstává, že nejpozději koncem ledna, často před vlastním zanesením infekce na své území, se mohly západní státy začít připravovat. Na rozdíl od SARS netrvalo vyhodnocení rizika osm měsíců, ale pouhý jeden. Svět byl tedy v mimořádně příznivé situaci, co se týče možnosti, jak efektivně zareagovat a epidemii zastavit jak na vlastním území, tak pomocí kooperace na mezinárodní úrovni.

\section{Západ}

Jak na PHEIC a další informace o přicházející epidemii reagoval západní svět?35 Nejprve je třeba vyzdvihnout vědeckou komunitu, která bezkonkurenčně rychle přispěla k vytvoření spolehlivého základu znalostí pro SARS-CoV-2 a nemoc covid-19. Úspěchy vědců jsou globální, mezinárodní, společné, podíleli se na něm západní i čínští vědci. Jedna z prvních odborných zpráv o nové nemoci na Západě je z 24. ledna: Bin Cao, šéf CDC z Pekingu s doktorátem ve virologii z Oxfordu, publikoval epidemiologická, klinická, laboratorní a radiologická data první skupiny pacientů v časopise The Lancet. Zde je stručný výčet dalších odborných milníků: ${ }^{36}$

nost je násobně nižší než v Číně) je třeba zdůraznit i to, že se jedná o protiepidemický úspěch demokratického režimu, patřící v r. 2020 mezi nejlépe hodnocené plné demokracie na světě. (V „Democracy Index“ časopisu The Economist obsadil Tchajwan 11. místo. Pro srovnání: Česko obsadilo až 31. místo těsně před africkými zeměmi Botswana a Cape Verde a ČLR až jedno z posledních míst, 151.), https://www.eiu.com/n/campaigns/democracy-index-2020).

35 Jak je již zmíněno v úvodu, „západním světem“ Horton myslí především Británii a USA. K ostatním západním zemím se vyjadřuje jen krátce v kapitole 4: uvádí katastrofální postup Španělska a Francie, celkem pochvalně je zmíněno Německo především díky robustnímu trasování a jasné komunikaci kancléřky Merklové (za sebe bych zde ale zdůraznil, že úspěch je to relativní s ohledem na Evropu a USA, nikoli ve srovnání s východní a jihovýchodní Asií), Švédsko označuje za „outlier“, s důrazem na individuální zodpovědnost.

36 Chaolin Huang Clinical features, The Lancet, 24. ledna 2020; Jasper Fuk-Woo Chan et al. A familia cluster of pneumonia ... The Lancet, 24. ledna 2020; Roujian Lu et al. Genomic characterization and epidemiology of 2019 novel coronavirus: implication for virus origins and receptor binding, The Lancet, 29. ledna 2020; Joseph T. Wu et al. Nowcasting and forecasting the potentia domestic and international spread of the 2019-nCov outbreak, The Lancet, 31. ledna 2020; Nanchan Chen et al. Epidemological and clinical characteristics of 99 cases ... The Lancet, 29. 
- 24. ledna: prokázán přenos z člověka na člověka (odborníci z Hongkongu a Šen-čen).

- 29. ledna: publikována genomická sekvence (tým z čínské CDC s prezidentem George Gao).

- 31. ledna: indikována vysoká pravděpodobnost globální epidemie (Gabriel Leunge spolupracující s WHO a Univerzitou v Hongkongu).

- Od konce ledna a během února: doloženo riziko mimořádné rychlosti zahlcení oddělení JIP a také velké ohrožení především starších pacientů.

Zatímco relevantní západní vědecká komunita zareagovala mimořádně rychle, nelze totéž říct o těch, kteří zodpovídají za vědeckou politiku: od konce ledna po celý únor a březen, asi sedm týdnů, vládní lékařští poradci př́chod nového viru zcela ignorovali. 3. března ministerský předseda Johnson doporučil mýt si ruce a tvrdil, že Británie je „extrémně dobře připravená“. 5. března v televizi prohlásil: „Možná bychom to mohli brát méně vážně, v celé populaci, aniž bychom zaváděli nějaká drakonická opatření.“37 Ostentativně si podával ruce se všemi, se kterými se setkal. 12. března vláda přestala trasovat. Graham Medley, jeden z vládních expertů, prohlásil, že je v pořádku nechat velké množství lidí infikovat, aby se vytvořila kolektivní imunita. ${ }^{38}$ Jedná se prý o „hezkou velkou epidemii“ (a nice big epidemic), kdy jde prý pouze o to, aby se nějak uchránila riziková část populace. Sir Patrick Vallance, hlavní poradce, mluvil dokonce na rovinu o cíli infikovat $60 \%$ britské populace. Až v průběhu března se začaly zavírat školy, bary a byl vydán př́ikaz zůstávat doma.

ledna 2020. Huijun Chen et al. Clinical characteristics and intraterine ... The Lancet, 12. února 2020. Xiabo Yang et al. Clinical course and outcomes ... The Lancet Respiratory Medicine, 21. února 2020. Srv. Také Isaac Ghinai et al. First know person-to-person ... in the USA, The Lancet, 12. března 2020.

$37, \ldots .$. Perhaps, you could sort of take it on the chin, take it all in the population without really taking as any draconian measures" Horton (2020, s. 50).

$38 \mathrm{~V}$ Česku tento přístup formulovala a pod vedením prof. Vladimíra Černého implementovala i klinická skupina Ministerstva zdravotnictví ČR. Srv. např. „Opatření vedoucí ke snižování vnímavosti populace vioči onemocnění covid-19 (tzv. přirozená imunizace)“, které stanoví, že „postupné prosazování systémových opatření navrhovaných MZ a vedoucích ke snižování vnímavosti populace vůči onemocnění COVID-19 (tzv. přirozená imunizace) považujeme za odborně správný postup a předpoklad obnovení ekonomiky a normálního života občanů." CSARIM, CSIM. (2020). 
Ještě 21. února, tj. tři týdny po PHEIC, považovala klíčová vládní vědecká rada vir za středně rizikový: „Došlo ke skutečně fatální chybě v úsudku, " píše Horton. „Vládní tvrzení, že britské zdravotnictví epidemii zvládlo úspěšně, je zavádějící už z toho důvodu, že bylo třeba odložit a radikálně omezit veškerou neakutní péči a zcela soustředit veškerou kapacitu na pacienty covid-19.“"39 Nepřipravenost britského zdravotnictví je obtížně zpochybnitelný fakt, doložený již z období před pandemií. ${ }^{\circ}$

K USA Horton poznamenává:

„Příběh covidu-19 v USA je jedním z nejpodivnějších paradoxů celé pandemie. Žádná jiná země na světě nemá takovou koncentraci vědeckých dovedností, technických znalostí a výrobních kapacit jako USA. Je to vědecká supervelmoc světa jako žádná jiná. Tento vědecký kolos přesto nedokázal úspěšně zúročit své odborné schopnosti a přenést je do politiky ... Za tři měsíce zemřelo v USA na covid-19 více lidí než během celé války ve Vietnamu. (...) První případ covidu-19 byl v USA hlášen 21. ledna ... 30. ledna hlásila americká Centra pro kontrolu a prevenci nemocí první případ přenosu viru z osoby na osobu ... Vláda přesto vyhodnotila riziko pro americkou veřejnost jako ,nízké‘.“41

Je pravdou, že 31. ledna, tj. den po PHEIC, Trump sice vyhlásil „public health emergency“ a zavedl některá omezení, ale Trumpova vláda i nadále postupovala liknavě a spíše slovy než činy; již během února bylo zřejmé, že trasování a testování v USA selhalo. Zároveň se zhoršujícím se postupem epidemie v březnu a dubnu začal Trump a politici jeho typu hledat zástupné viníky: „...národní selhání byla přetavena do meziná-

39 „There was a genuinely fatal error of judgement“ (Horton 2020, s. 54). „The official government narrative was that the UK's national health service had succeeded in coping with the epidemic. Yet that assesment was only true because thousands of planned appointments and elective procedures were cancelled to create the capacity for the succeeding wave of Covid-10 admissions." (Horton 2020, s. 55).

40 Horton zmiňuje cvičení Cygnus z r. 2016, simulaci, která měla prověřit národní zdravotní systém. Výsledkem bylo 200 ooo mrtvých. Z těchto a podobných varovných signálů nebylo vyvozeno žádné praktické poučení.

41 Horton (2020, s. 46). 
rodních útoků." ${ }^{42}$ Proti komu se politici začali obracet ve své snaze zakrýt svá vlastní selhání? Nejčastěji proti WHO anebo ČLR. Extrémním př́kladem tohoto přístupu je zmíněný americký prezident. Jeho útok vưči WHO dokonce nabyl jakési podoby studené války, jež vedla $k$ naprostému přerušení spolupráce $\mathrm{s}$ touto nezastupitelnou mezinárodní institucí. 43 Tento krok považuje Horton za čin na úrovni „zločinu proti lidskosti“:

„Jsem přesvědčen, že rozhodnutí prezidenta Trumpa zastavit financování WHO uprostřed globální pandemie představovalo zločin proti lidskosti. Je to tvrzení přehnané? Ne, a zde je důvod. WHO existuje za účelem ochrany zdraví a dobrého života (wellbeing) národů světa. Zločin proti lidskosti je vědomý a nelidský útok proti lidem. Prezident Trump tím, že útočí na WHO a oslabuje ho, zatímco tato instituce dělá vše pro to, aby chránila národy v nejzranitelnějších zemích světa, podle mého názoru splňuje kritéria pro násilný čin, který mezinárodní společenství nazývá zločinem proti lidskosti."“4

Podobně jako americká, i britská vláda varovné signály relevantních odborníků na veřejné zdraví svévolně ignorovala. Několik měsíců po PHEIC, po hrůzném množství úmrtí a částečném kolapsu britského zdravotnictví, ministerský předseda Boris Johnson tvrdí, že „účinky [viru] jsme [v dané době] plně nechápali“. Horton neváhá použít i silná slova o tom, že mediálnímu narativu dominuje „mašinérie vládní dezinformace“ a dochází dokonce ke „kremelskému“ zatajování a cenzurování dat, např. o úmrtí. ${ }^{45}$ Skutečnost je tedy taková, že bez ohledu na to, co se stalo či děje v ČLR či WHO, došlo na straně vlád západních zemí k žalostnému selhání při ochraně veřejného zdraví: rizika nového viru byla známa, a přesto nebyly učiněny dostatečné př́ípravy

42 Tamtéž, s. 26.

43 „Globalism, international solidarity and cooperation between states were sacrificed in favour of unilateralism, nationalism and populist self-interest. It was a sad and dissappointing contrast to the unanimity among nations following the SARS outbreak in 2002-3.... The war against WHO was an unexpected twist in the story of COVID-19.“

44 Horton (2020).

45 „Kremlinesque in its audacity ... the machine of government disinformation“ Horton (2020, S. 95-96). 
na to, aby se zabránilo šíření infekce. ${ }^{46}$ Pokud se někdo retrospektivně snaží přenést odpovědnost na mezinárodní instituce či zahraniční vlády, nejedná v dobré víře.

Někdy se lze setkat $\mathrm{s}$ tvrzením, že experti měli zpočátku různé protiřečící si nepřesné modely, nejistota, jaké intervence podniknout, prý byla vysoká. Toto tvrzení nemůže dle Hortona obstát: počet ohrožených životů mohl spočítat „každý gramotný student“.47 Od ledna bylo známo, že covid-19 je smrtící nemoc. (I kdyby smrtnost byla jen dvojnásobkem sezónní chřipky, jak někteří extrémnější autoři tvrdili, jednalo by se při vyšším indexu nakažlivosti o mnohem ničivější nemoc než chřipka.) Bylo zřejmé, že se bliží nebezpečná epidemie, bylo zřejmé, že je třeba monitorovat hranice, testovat a trasovat, podporovat fyzické distancování, hygienu a další nefarmakologické postupy - a přesto se to nedělo. A když už se to začalo dít, dělalo se „příliš málo, příliš pozdě“. ${ }^{48}$ Pokušení přenášet následně zodpovědnost za vlastní selhání na WHO či ČLR je sice velké, ale jedná se o „přepisování historie“. 49

46 „Together, these failure constituted an extreme example of state negligence - a failure of governments to exercise their duty of care by ignoring evidence of possible danger, thereby exposing people to the risk of severe, sometimes fatal, harm. The evidence shows that governments could reasonably have been expected to know the risk posed by this new virus. ... It was within the power of governments to have prevented this human crisis. They failed to prevent. They omitted to save. ... Governments were causally complicit and responsible for these failures." Horton (2020, s. 86).

47 Takto: počet obyvatel krát míra promořenosti pro skupinovou imunitu krát smrtnost. Srv. další poznámku pod čarou s Hortonovým výpočtem pro Británii.“

48 „What is so mysterious is that it didn't need the predictions of scientists at Imperial College London in March to estimate impact ... Any numerate school student could make the calculation. With a mortality of 1 per cent among 60 percent of a UK population of some 66 million people, the UK could expect almost 400,00o deaths. The huge wave of critically ill patients ... would quickly overwhelm the NHS. The UK's best scientits had known since the first report from China in January that COVID-19 was a lethal illness. Yet they too did too little, too late." Horton (2020, S. 52).

49 „This message of gross incompetence is not welcome in Western political, medical or even media circles. It conflicts with a geopolitical narrative that casts China as a negative and destructive influence in international affairs. Instead, the preference has been to blame China and WHO. The claim is that China hid the fact of Covid-19. The claim is that WHO colluded with China in a cover-up of enormous proportions. ... There are many reasons to be critical of contemporary China ... [But] in the case of Covid-19, China's scientists and physicians acted decisively and responsibly to protect the health of the Chinese people ... They warned their government, their government warned WHO, and WHO warned the world. Western democracies failed to listen to those warnings. There are questions for the Chinese government and WHO to answer. But to blame China and WHO for this global pandemic is to rewrite the history of Covid-19 and to marginalize the failings of Western nations.“ (s. 87-88). ... „It is understandable that Western countries would prefer to diminish their own responsibility. Their governments are facing di- 
Západní vlády zprvu na epidemii nereagovaly, čímž již při první vlně došlo ke zbytečně velkým zdravotním i hospodářským ztrátám. Tolik Hortonovo hodnocení první části roku 2020. Došlo ke zlepšení situace v druhé části r. 2020? Zde můžeme retrospektivně říci to, co jsem zmiňoval již v úvodu, totiž že ani po bezprostředním zvládnutí první jarní vlny nedošlo ve většině západních zemí $\mathrm{k}$ rozhodnutí epidemii marginalizovat a radikálněji chránit veřejné zdraví. Až na výjimky tyto země setrvaly i nadále při strategii mitigace, tj. snahy o ochranu zdravotních systémů před kolapsem, navzdory tomu, že bylo zřejmé, že tato strategie povede v dlouhodobé perspektivě $\mathrm{k}$ mohem větším ztrátám na zdraví a životech obyvatel než strategie marginalizační. Tento fakt, myslím, jen dále posiluje tezi tohoto článku, totiž vnitřního selhávání většiny západních zemí. Zatímco v lednu 2020 byla situace pro mnohé odborníky a činitele zodpovědné za veřejné zdraví do jisté míry nejasná a jejich neznalost snad do jisté míry omluvitelná, o několik měsíců později je tato tolerance $\mathrm{k}$ počáteční neznalosti a planým spekulacím nemožná. Přesto se mnohá selhání z první poloviny roku opakovala i v polovině druhé a důvody jsou tedy hlubší než jen pomalé zpracování vědeckých poznatků či různé biasy, kterými jsou i odborníci zatíženi. ${ }^{50}$

\section{SARS}

Jaké jsou př́ičiny selhání západních zemí? Klíčové vysvětlení by mohlo dle Hortona spočívat v tom, že ČLR a další asijské země měly již zkušenost $\mathrm{s}$ vysoce smrtným SARS, kdežto západní země pouze s méně nebezpečnými epidemiemi sezónní chřipky. Než se v závěru této sekce

fficult question about what they knew and when they knew it. ... Placing responsibility for the pandemic on a country already distrusted by many citizens and an international agency that most people had barely heard of were easy diversions. It seems to work. Anti-China sentiment grew." Horton (2020, s. 89).

50 Ani selhávání při ochraně veřejného zdraví při první vlně není ovšem zcela omluvitelné v tom smyslu, „že se jednalo o legitimní pohled na věc“. Mnozí např. na jaře vydávali Švédsko s mitigační strategií za vzor s tím, že i když má třeba ve srovnání se sousedním Norskem či Finskem mnohonásobně menší úmrtnost, na podzim bude situace jistě opačná. Je tedy prý třeba „počkat do konce roku“. Nejenže se empiricky tato predikce ukázala jako mylná, nebot druhá vlna ve Švédsku menší nebyla a očekávaná, tř̌ebaže prý nezáměrná, kolektivní imunita nenastala, ale od počátku lze argumentovat proti švédskému přístupu takto: $V$ případě nejistoty, zda nějaká intervence na ochranu veřejného zdraví bude efektivní či nikoli, je morálně správné zvolit „pokus o ochranu s rizikem selhání“ před „rezignovat, protože ostatním se to možná dřive či později také nepovede“. 
vrátím k otázce, zda toto vysvětlení obstojí, připomeňme si základní data ohledně epidemie SARS a zhodnot’me si její význam.

SARS byl poprvé zachycen v listopadu 2002 jako případ „neobvyklého zápalu plic“ ve městě Fo-šan, které se nachází v provincii Kuang-tung, asi tisíc kilometrů jižně od Wu-chanu. Kvůli oslavám lunárního nového roku bylo ovšem šíření tohoto zápalu plic vesměs ignorováno. Teprve 31. ledna, kdy bylo dle údaju ČLR již infikováno 305 lidí a zaznamenáno 5 úmrtí, se zpráva o nové nemoci dostává k WHO. Další fáze nastává 21. února, kdy se na pokoji 911 hotelu Metropol v Hongkongu ubytoval infikovaný lékař z Kuang-tung. Následných 8000 doložených případů je vytrasováno právě k tomuto superpřenašeči z hotelu Metropol. PHEIC bylo vyhlášeno až 13. března, ovšem země světa na něj zareagovaly rychle, koordinovaně a efektivně, takže se nemoc podařilo zastavit a virus byl v květnu 2003 eradikován.

Propuknutí epidemie SARS bylo tedy poměrně krátké a omezené jen na malý počet zemí. Dopady této epidemie byly ovšem obrovské až epochální. Horton poukazuje na několik věcí, kterých si lze na událostech kolem SARS povšimnout: ${ }^{1}$

- ČLR do velké míry selhala: projevil se slabý zdravotní systém a potlačování evidence a kooperace vedlo k mezinárodní ostudě; dokonce i zdrženlivá WHO otevřeně kritizovala přístup ČLR (nový prezident Hu Jintao následně odvolal ministra zdravotnictví i pekingského starostu, došlo k masivním investicím do zdravotnictví a k rozhodnutí, že ČLR již nikdy nebude takto pokořena).

- Mezinárodní komunita si sice s novou nemocí poradila tentokrát dobře, nicméně se zřetelně potvrdilo varování, že v globalizovaném světě budou podobné epidemické události četnější a př́prava na ně by měla být jednou z národních priorit. ${ }^{2}$

- Mnohé epidemie nelze řešit jen lokálně, zásadně důležitá je kooperace a koordinovaný postup na mezinárodní úrovni.

- Nezvládnuté epidemie přinášejí obrovské ekonomické náklady; posílení připravenosti na zdravotní rizika je navíc i otázkou národní bezpečnosti.

51 Horton (2020, s. 30).

52 Knobler et al. (2004). 
- Dříve než jsou vyvinuta účinná farmakologická řešení (léky či vakcíny), což může trvat i značnou dobu, je třeba rychlých, nejlépe preventivních protiepidemických nefarmakologických intervencí: „sledování, raná detekce, izolace, trasování kontaktů, karantény, navýšení kapacity zdravotních systémů ... efektivní komunikace s veřejností."53

Horton dokonce souhlasně cituje tezi Davida Fidlera, že SARS patří mezi klíčové geopolitické události počínajícího století, protože se jedná o „první post-vestfálský patogen“:

„Od roku 1648 do roku 2002-3 bylo možné infekční nemoci - vlastně všechny nemoci - do značné míry zvládnout v rámci státních hranic. Po více než tři století byly mezinárodní vztahy utvářeny třemi principy: principem národní svrchovanosti, neintervenováním do záležitostí svrchovaných států a mezinárodním právem založeném na konsenzu ... ...pandemie vládní všemohoucnost narušila. ...SARS zahájil novou éru post-vestfálského veřejného zdraví - zdraví, které přesahuje státní hranice a národní suverenity. A sama tato éra byla slavnostně inaugurována spektakulárním úspěchem: „Globální kampaň proti SARS dosáhla vítězství, které se dostane do análů veřejného zdraví a mezinárodních vztahů." 54

Kromě SARS jsme navíc měli i následně další dvě významné epidemie nových patogenů, totiž ebolu (2013-14) a ziku (2015-16). Je tedy zřejmé, že se SARS opravdu nastává nová éra, kdy epidemie budou i nadále výrazně ovlivňovat nejen oblast globálního zdraví, ale spoluurčovat i socioekonomické a geopolitické trendy na naší planetě. 55

53 „The public health response that was needed was also clear - surveillance, early detection, isolation, contact tracing, quarantine, accumulating surge capacity within the health system ... and effective communication to the public." Horton (2020, s. 31).

54 Horton (2020, s. 32-33) a Fidler (2004). Dle mého názoru zde Horton s Fidlerem kladou globální spolupráci do př́liš silného kontrastu k národní suverenitě. Problematické je i tvrzení, že SARS je první post-vestfálský patogen; tento status by mohl připadnout i španělské chřipce.

55 Další z nových nemocí, totiž MERS se obtížně přenáší z člověka na člověka, tj. jeho nebezpečí není tak výrazné; z dřívějších nových infekčních nemocí stojí za zmínku: Hendra (1994), Nipah (1998). Odborníci již více než dvě desetiletí poukazují na rostoucí počet nových patogenů a uvádí ho do souvislosti s environmentálními změnami a zvýšenou mobilitou (Jones et al. 2008). 
Jakkoli lze souhlasit s Hortonovým hodnocením významu SARS jako takovým, otázkou je, zda zkušenost se SARS obstojí jako hlavní vysvětlení reakcí zemí na SARS-CoV-2. Celkem byl SARS zaregistrován v 29 zemích a teritoriích (počet případů 8096 a počet úmrtí 774). Patří mezi ně nejen ty, které si se současnou epidemií poradily úspěšně (ČLR, Hongkong, Tchajwan, Macao, Singapur, Vietnam, Thajsko, Mongolsko, Austrálie, Nový Zéland, atd.), ale i mnohé země, které patří mezi nejneúspěšnější (USA, Británie, Francie, Itálie, Brazílie, Švédsko, Kanada, atd.). Nezdá se tedy, že by zkušenost se SARS jako taková byla dostatečným vysvětlením, proč západní země během současné pandemie selhaly: je třeba i následného správného vyhodnocení, uchování a předávání zkušenosti s epidemiemi a budování efektivních proti-epidemických struktur na ochranu zdraví populace.

\section{E. Příčiny selhání}

Pokud nelze jednoznačně identifikovat chybějící zkušenosti se SARS jako hlavní příčinu selhání západních zemí, o jakých dalších př́ičinách lze uvažovat? Horton se k tématu vyjadřuje opakovaně, nesystematicky a na vícero místech knihy. Domnívám se, že příčiny a slabiny současného přístupu západních zemí, o nichž Horton mluví, lze rozdělit do tří skupin: epistemické, politické a morální.

Za epistemické prríčiny selhání lze považovat následující:

- ignorování nových dat a jejich pomalé hodnocení bez proaktivní snahy zjistit více; 56

- vyloučení některých relevantních disciplín a odborníků $\mathrm{z}$ diskuse; ${ }^{57}$

- neschopnost práce s nejistotou a pravděpodobností, v jejímž rámci je třeba se rozhodovat; 58

- fragmentace disciplín a odborností: „nadměrně specializo-

56 „... UK's SAGE ... did not consider research published at the end of January which set out the magnitude of the threat ... did not reach out to those with first-hand experience of what was taking place in China." Horton (2020, s. 102).

57 „What constitutes knowledge about a risk, the assumptions we make about that risk, which evidence is ruled in and out of scope for consideration, who is invited to the table to discuss risks, and what type of science is used to shape advice to politicians." Horton (2020, s. 102).

58 Horton (2020, s. 112). 
vaná dělba práce ... zdrženlivá k praxi“;;5

- absence kritického diskurzu: umlčování kritiků vládního postupu, pokud se např. snažili poukázat na úspěšnější postupy jiných zemí; ${ }^{\circ}$

- falešný optimismus: jakkoli je i zdrojem pozitivní síly, nesmí vést $\mathrm{k}$ bagatelizaci reálných rizik. ${ }^{61}$

Epistemický problém, kterému věnuje Horton největší pozornost, je tzv. infodemie, tedy „nadmíra informací, at’ už pravdivých či nepravdivých, které zabraňují efektivní odpovědi na epidemii. Komu v této záplavě věřit?“ ${ }^{62}$ Infodemii, jejímž nejvýraznějším projevem je šíření misinformací, tj. nepravdivých informací, či dokonce dezinformací, tj. nepravdivých informací s úmyslem klamat, Horton rozděluje do čtyř oblastí: ${ }^{63}$

- pưvodu (např. nepodložená domněnka, že epidemie vznikla záměrně či zatajením nehody, jak tvrdil např. Trump, či že vznikla v souvislosti se sítěmi $5 \mathrm{G}$ );

- symptomů a přenosu (např. někteří hinduističtí nacionalis-

59 Horton zde souhlasně cituje z knihy Ulricha Becka z r. 1986 Riziková společnost, dle níž hrozbou není jen ,ignorance“ ale i (nadmíra) „knowledge“: „overspecialized division of labor, their concentration on methodology and theory, their externally determined abstinence from practice - the sciences are entirely incapable of reacting adequately to civilizational risks" Beck (2004, s. 183) in Horton (2020, s. 101).

60 Horton (2020, s. 113 a 115).

$61, \ldots$ can also blind us, imbue with a sense of power and overconfidence, and mask real dangers that to be embraced, understood and addressed with humility and care. Human beings are condemned to suffer from optimism bias. We tend to overestimate the likelihood that good things will happen in life. ... An appeal for greater pessimism in our dealings with the world may not feel like an inspiring call to arms to avert the next pandemic. But if the scientists and politicians who gave advice and took decision on our behalf had adopted a little more pessimism in their predictions and policies, the deaths of hundreds of thousands of their fellow citizens around the world would have been avoided. ... We can protect and, indeed, intensify our hope through a perspective that does not mask the works that can happen to us." Horton (2020, s. 117).

62 Horton (2020, s. 38).

63 Horton (2020, s. 38-9). Vhodnější by bylo patrně rozdělení kategorie „symptomů a přenosu“ na dvě; pochybovat lze i o vhodnosti některých příkladů, které Horton uvádí. Infodemie je komplexní téma, které je třeba zkoumat i s ohledem na širší kontext: historická komparace s dezinformováním o epidemii HIV/AIDS, morální aspekty cenzury, role médií při ochraně veřejného zdraví atd. Zdroje současné infodemie jsou různorodé od státních aktérů až po dobrovolné nadšence. Významnou dezinformační roli hrají i někteří politici: „... based on a total sample of over 38 million articles published in English-language ... We found that media mentions of US President Donald Trump within the context of COVID-19 misinformation made up by far the largest share of the infodemic. Trump mentions comprised $37,9 \%$ of the overall misinformation conversation, well ahead of any other topics." (Evanega et al. 2020). 
té obvinili muslimy z korona-džihádu; xenofobii a rasismus šíril i Trump tím, že vir v kontextu rostoucího anti-asijského resentimentu nazýval v rozporu s mezinárodními pravidly „čínský vir“) 64 ;

- léčby (např. pomocí vitamínu C či koloidním stř́ibrem; dle Trumpa potenciálně vnitřním užitím dezinfekce či ozařováním);

- významu (často docházelo k bagatelizaci, např. dle Trumpa se jedná o nemoc nebezpečnou stejně jako sezónní chřipka).

Je zřejmé, že v situaci, kdy je třeba rychle a správně zhodnotit informace, na nichž závisejí zdraví a životy mnohých, je důležité postupovat zodpovědně, interdisciplinárně, konsenzuálně, ovšem zároveň velmi rychle. V mnohých zemích k podobnému postupu nedošlo, což poškodilo důvěru populace v odborníky a erodovalo možnost efektivního a rychlého protiepidemického postupu. ${ }^{65}$

Globální vědecká komunita bezkonkurenčně rychle přispěla k vytvoření spolehlivého základu znalostí o viru SARS-CoV-2 a onemocnění

64 Někdo by mohl říci, že běžně mluvíme o „španělské chřipce“ či „britské mutaci“, aniž bychom tento diskurz brali jako xenofobní. Domnívám se, že je důležité vnímat emotivní aspekt terminologie v jejím kulturním kontextu: výše uvedená označení v západních společnostech k předsudkům a násilí nepodněcují. Jinak tomu je s termínem „čínský virus“. V USA došlo během roku 2020 k prudkému nárůstu násilí proti Číňanům a obecně Asiatům, včetně vražd, při nichž hrála nepochybně motivační roli „odplata za čínský virus“. Podobně by bylo jistě nevhodné v nějaké africké či asijské společnosti označovat nějakou nemoc jako „západní“ v př́ípadě, že by mohlo docházet k nárůstu násilí proti bělochům. A naopak v rámci čínské společnosti nemusí mít např. termín „wuchanský virus“ nebezpečné negativní konotace.

65 V samotné Británii a USA poměrně záhy došlo mezi odborníky na veřejné zdraví a epidemiology ke konsenzu ohledně výhod marginalizační strategie. Naneštěstí ale v oblasti rozhodování zvítězili obhájci krátkodobých politických a ekonomických zájmů, kteří prosazovali jiná řešení navzdory předvídatelným ničivým dlouhodobým dopadům. Zbytečné a destruktivní zmatky také nastaly v prvních měsících při medializaci některých spekulativních a nepodložených názorů odborníků, srv. pronikavá analýza Yong (2020). V Česku na rozdíl od zahraničí ke konsenzu mezi odborníky nedošlo, resp. se zdá, že relevantní odborníci MZ ČR podpořili „přirozenou imunizaci“, neboli promoření (srv. poznámka 37). Hledání důvodů by patrně vyžadovalo samostatné zkoumání, zde bych rád alespoň zmínil následující vysvětlení: Integrativní, interdisciplinární obor veřejné/globální zdraví v Česku neexistuje. Za experta na epidemie se považuje jakýkoli lékař, i kdyby byla jeho vlastní specializace od tematiky epidemie a veřejného zdraví sebevzdálenější (např. stomatologie, onkologie, anesteziologie, atd.). Schopnost porozumět epidemiím přitom vykazují daleko více např. matematici, datoví vědci a ekonomové než lékaři. Lékařské vzdělání je totiž většinou zaměřeno spíše klinicky, nemoc z tohoto hlediska je sledována abstrahovaně jako nezávislý jev. Pro porozumění epidemii je přitom zásadní právě závislostní charakter přenosu nemocí, což je aspekt nemoci, pro který většina lékařů nemusí mít dostatečnou intelektuální průpravu. 
covid-19. „A přesto řešení covid-19,“ píše Horton, „představovalo v mnoha zemích největší selhání vědní politiky (science policy) této generace. Co se stalo?"66 Horton mluví o několikerých selháních současných režimů západních zemí, a zde lze mluvit o politických př́ičinách:

- zneužití moci: doložené mj. naprostou absencí proaktivního ověření si varovných signálů, které přicházely z WHO a dalších zdrojů; ${ }^{67}$

- komplicita: především při zakrývání vlastního selhání a vyvolávání klamného zdání, že země v porovnání s ostatními zeměmi zvládá epidemii dobře ${ }^{68}$

- nekomunikativnost: osvěta byla nedostatečná a opožděná. ${ }^{69}$

Obzvláště důležitým faktem, který indikuje selhání západních politiků, je jejich podíl na dezinformování a lhaní:

„Už jsem hovořil o ... infodemii ..., která se objevila během krize covid-19. Ještě překvapivější a neočekávanější bylo, že samotné vlády se uchýlily k politickým dezinformačním kampaním, aby obhájily svou vlastní roli, kterou sehrály při zvládání epidemie. Tyto snahy o přepsání příběhu covid-19je důležité zdokumentovat. Stejně jako došlo k boji o potlačení epidemie, existuje také boj o kontrolu nad veřejným pohledem na vládní zvládání epidemie. Britští politici například tvrdí, že [ani] na počátku epidemie se nepokoušeli

66 Horton (2020, s. 41).

67 „It was an abuse of power because the system of science policy formation failed to act on clear and unambiguous signals from China that culminated in a PHEIC from WHO on 30 January. When a PHEIC was called, government scientific advisory committees ... should have urgently started asking questions. They should have contacted their counterparts in China and Hong Kong - Bin Cao, George Gao, George Leung - to seek first-hand testimony about what was happening. They should have called WHO country office in Beijing to understand their assesment of the situation in Wuhan. If they had done so, our most senior scientific advisors would have heard the same messages so starkly reported in their published papers from January - a pandemic of a bitterly toxic virus on its way to Europe. The fact that they apparently took none of these actions is what constitutes the abuse of entrusted power." Horton (2020, s. 58).

$68, \ldots$ scientists and politicians agreed to act together in order to protect the government, to give the illusion that the UK was an ,international exemplar' in preparedness and made the right desicions at the right time, based upon the science." Horton (2020, s. 55).

$69, \ldots$ the messages delivered to the public were often too little, too late“ Horton (2020, s. 86). 
o politiku skupinové imunity. Prohlášení jich samých i jejich vědeckých poradců jasně dokazují opak.“70

Je zřejmé, že věda a zdravotnictví je i záležitostí politickou. ${ }^{71}$ To ovšem neznamená, že politikové mají či mohou zasahovat do procesů kritické diskuse ve vědecké komunitě jinak, než vedeni zájmem o ochranu veřejného zdraví a dalších důležitých hodnot společnosti. Je možné, že jisté aspekty „intenzivního kapitalismu“ a západních politických institucí bude třeba přehodnotit a to i po právní stránce, zdá se totiž, že sociální předivo mezi lidmi bylo narušeno a lidé jsou bráni jako pouhý nástroj. ${ }^{72}$

V souvislosti se lhaním se dostáváme i k tématu morálních prríčin selhání. Horton si je vědom zásadní role, kterou hraje etika v souvislosti s koronakrizí: „Covid-19 není jen krizí zdravotní, je něčím daleko horším ... je krizí samotného života ... virus ukázal na hybris našeho lidského druhu a jeho vlivu na tuto planetu." ${ }^{73} \mathrm{Na}$ jiném místě mluví Horton př́mo o nové příležitosti promyslet „etické základy naší společnosti“ a o důležitosti „uctít ztracené životy tím, že budeme žít jinak“.74 Nicméně navzdory morálnímu zaujetí, které se knihou vine jako červená nit, se Horton systematicky etickému selhávání v užším smyslu slova věnuje daleko nejméně. Otázky, které je třeba dle mého názoru v souvislosti s koronakrizí klást a jež si Horton přímo neklade, se týkají specificky západních morálních intuicí: Jaká hodnota je přisuzována životu starších lidí v západních společnostech? Jak velký význam má mezigenerační rodina? Plánujeme život spíše z hlediska dlouhodobého, či je důraz kladen na krátkodobé instantní uspokojení? Nebyla vlažná reakce západních zemí a razantní reakce východních zemí zapříčiněna

70 Horton (2020, s. 92).

71 „The risks we faced, and continue to face, are not only from the new virus. Those risks are also embedded in the system we have created and put in place to review and adjudicate on the threat of pandemic - the regime of science policymaking." Horton (2020, s. 101).

72 „Capitalism has many virtues. But the intense version of capitalism that has emerged over the past forty years has weakened something essential in the social fabric of our societies. Those weaknesses contributed to the tragic toll of deaths. After covid-19 it is no longer acceptable to see people as means rather than ends." Horton (2020, s. 126).

73 Horton (2020, s. 96). Horton zde vychází z prací francouzského antropologa a sociologa Didiera Fassina (2018), dle něhož nemoc není jen biologická záležitost, ale má svůj sociální a politický aspekt (Horton 2020, s. 98).

74 „COVID-19 has provided us with an opportunity to rethink the ethical basis of our society. The virus took so many lives. We can't allow ourselves to return to our old worlds ... To honor the lives lost we have to live differently." Horton (2020, s. 126). 
i tím, že covid-19 zabíjí výrazně častěji především starší lidi? Změnila by se reakce, kdyby zabíjel spíše mladé lidi, jako tomu bylo u španělské chřipky?75

Lze považovat příčiny či faktory vysvětlující selhání některých zemí za kompletní? Domnívám se, že nikoli. Jakkoli lze jen obtížně nesouhlasit s faktory, které identifikuje Horton, je zde i řada dalších vlivů, především faktor př́tomnosti či absence dlouhodobého strategického myšlenív dané společnosti. (Epidemii zvládají lépe země, které na počátku porozuměli tomu, že se jedná o poměrně dlouhodobé riziko $v$ řádu minimálně dvou let a $\mathrm{s}$ touto perspektivou hledaly i prostředky $\mathrm{k}$ jejímu zvládnutí; hưře pak země, které uvažují o problémech pouze $\mathrm{v}$ krátkodobém horizontu momentálního zisku a ztráty.) ${ }^{76}$

Horton ani neuvažuje o pojetí, které, zdá se, je vlivné mezi některými českými lékaři, totiž, že průběh epidemie covid-19 je dán primárně biologicky, $\mathrm{v}$ rámci různých společností probíhá téměř shodně, maximálně s časovým posunem, a efektivní dlouhodobá intervence na ochranu populace před patogenem SARS-CoV-2 je nemožná. Ve své naivní podobě se jedná o natolik absurdní stanovisko z hlediska elementárních principů disciplín, jako jsou epidemiologie a veřejné/ globální zdraví, že by je Horton patrně ani nepovažoval za hodné odpovědi. $\mathrm{V}$ revidované podobě, totiž že nefarmakologické intervence jako jsou RRR (ruce, roušky, rozestupy), lockdowny, či TTI (test, trace, isolate) přináší společnosti v nejlepším př́ípadě jen okrajové a dočasné výhody, ovšem daleko větší nevýhody, by se patrně bylo možné tímto stanoviskem zabývat, nicméně Horton tak nečiní. Adekvátní vyvrácení tohoto revidovaného stanoviska přesahuje zaměření tohoto článku, zde pouze konstatuji, že jak v naivní, tak $\mathrm{v}$ revidované podobě je toto stanovisko $\mathrm{v}$ rozporu s vědeckým konsenzem a existuje bohatá odborná literatura, z níž vyplývá jeho neudržitelnost.77

75 To, že západní, na rozdíl od východních společností, reagovaly vlažně na nemoc zabíjející převážně starší osoby, uvádím do souvislosti s důrazem na důstojnost stáří a mezigeneračních vazeb v čínských (konfuciánských) a budhistických kulturách (Kerles 2020a). Při použití současných experimentálních metod se nicméně zatím tato domněnka př́liš nepotvrzuje, srv. Löckenhoff et al (2015), jakkoli náznaky v její prospěch existují, nejnověji např. v oblasti výzkumu morálních intuicí v oblasti autonomních vozidel, srv. Awad et al (2018).

76 K tomu můj rozhovor, srv. Horák (2020).

$77 \mathrm{~K}$ vědeckému konsenzu srv. Černý et al. (2020) s dalšími odkazy. Teze o primárně biologických faktorech průběhu epidemie je zcela v rozporu s čímkoli, co o epidemiích víme, srv. např. Saracci (2010). Poměrně výstižně charakterizuje epidemii Koubský (2020): „Epidemie rovná se patogen 
Kromě faktorů, které Horton nějakým způsobem identifikuje či rozebírá a které jsem rozčlenil do tř́i skupin (epistemické, politické, etické), je zde i celá doména faktorů, které Horton nezvažuje vůbec, resp. okrajově (např. mluví-li o solidaritě). Tyto faktory lze nazvat jako kulturní, kandidáty by pak mohlo být náboženství, „životní filosofie“, interpretace zdraví a nemoci, apod. ${ }^{78}$ Precizněji zachytit kulturní faktory není snadné, jeden z kulturních faktorů zkoumal tým americké behaviorální psycholožky Michele Gelfandové, totiž přísnost/volnost kultur (tightness/loosness) a jejich zvyklostí. Podařilo se ukázat na zajímavou korelaci, při níž společnosti s vysokou mírou volnosti vykazovaly ve sledovaném období pětinásobné množství případů covid-19. Je ovšem třeba i poukázat na to, že společnosti se srovnatelnou mírou přísnosti/volnosti, např. Švédsko a Thajsko se často výrazně liší z hlediska odpovědi na covid-19, např. co do úmrtnosti pro zmiňované země tisíc dvěstěkrát. To indikuje daleko zásadnější roli dalších faktorů, at již kulturních či jiných. ${ }^{79}$

Zkoumání příčin/faktorů vysvětlujících míru úspěšnosti při ochraně veřejného zdraví té které země či toho kterého civilizačního okruhu, bude patrně živé téma i do budoucnosti. V tomto článku jsem identifikoval tři

(v tomto případě koronavirus SARS-CoV-2) plus chování jednotlivce (péče o vlastní zdraví, hygiena, počet kontaktů...) plus chování a pravidla společnosti (zákazy, omezení, lockdown, ale také převládající životní styl, míra bohatství, politické zřízení, převažující společenská filosofie...). Můžete přičíst ještě čtvrtý člen, prostředí (klima, znečištění...), anebo ho můžete zahrnout do pravidel a fungování společnosti.“ Kromě chování jednotlivce je třeba doplnit ke Koubského charakterizaci i biologické vlastnosti organismu a jeho imunitního systému (v mladší a zdravější populaci může mít epidemie mírnější průběh). V Česku zdůrazňují čistě př́írodní charakter průběhu epidemie covid-19 a nemožnost efektivní intervence na ochranu populace před patogenem SARS-CoV-2 prof. Vladimír Černý a prof. Ladislav Dušek. Pro odkazy na mediální vystoupení prof. Černého, srv. Jedlička (2021).

78 Srv. příspěvky, na kterých jsem se podílel: Mutemwa, M., Zvánovcová, V., Helová, A. \& Novotný, D. D. (2021, v recenzním řízení): „Role of religion, philosophy of life, traditional medicine, and past experiences in Covid-19 pandemic resilience: Zambia case study.“. A dále: Kerles (2020a), Kerles (2020b), Horák (2020).

79 Další kategorie faktorů, které Horton neuvažuje, jsou př́rodního rázu, především klima ageografie. Jakkoli teplé klima i ostrovanství patrně přináší nějaké výhody, nelze je přeceňovat, a je i otázkou, zda by se při pečlivějším globálním komparativním zkoumání nějaká korelace vůbec nalezla. Koronavirus se sice snadněji šiří v chladnějším klimatu, bez problémů ovšem zvládne i šíření v teplém klimatu. Navíc je v zemích s vysokými denními teplotami rozšířena umělá klimatizace, která riziko šíření viru zvyšuje. Podobně i ostrovanství přináší možné výhody při monitoringu hranic před importem nových nákaz, ale i ostrovy jsou lodní a leteckou dopravou často natolik propojeny s jinými zeměmi, že bez cílené zdravotní politiky zabránit importům infekce (např. požadavkem dvoutýdenní karantény) ostrovanství žádné podstatné výhody nepřináší. 
typy důvodů, kterými se alespoň stručně zabývá ve své knize Horton, a poukázal jsem na význam kulturních faktorů, které nijak nezmiňuje. Ani kulturní faktory ovšem nepovažuji za naprosto centrální. Konečné vysvětlení úspěchu některých zemí a selhání jiných bude mít jistě „kompozitní" charakter, tj. žádný jednotlivý faktor či typ faktorů nebude sám o sobě dostačujícím vysvětlením, daný faktor bude ovlivňovat jen do jisté míry. Jeden faktor nicméně považuji za zcela klíčový a domnívám se, že implicitně je prrítomen i v Hortonově přístupu, jak jsem se snažil ukázat i v tomto svém článku. A tím je schopnost rychlého zhodnocení dostupné evidence a volba strategie marginalizace/eliminace. Jen tato strategie totiž může radikálně ochránit zdraví dané populace před devastací novým patogenem s parametry jako je SARS-CoV-2.

Odkud pramení schopnost/neschopnost správné a včasné volby marginalizační strategie? Jedním z důvodů dle mého názoru bude existence kvalitních interdisciplinárních studií veřejného/globálního zdraví v dané zemi a robustnost místních struktur, které vzdělávání v této oblasti předpokládá a spoluvytváří. Bez důvěryhodné epistemické autority v oblasti veřejného/globálního zdraví je totiž vysoce nepravděpodobné, že daná země a její populace bude schopna porozumět fenoménu nové infekční choroby a včas na něj adekvátně reagovat. Kvalitní pandemické plány sice do jisté míry mohou připravit zemi na novou hrozbu, ale tyto plány bez dobrých odborníků, právního zakotvení, nácviku pandemických situací a spolupráce napřrič všemi společenskými vrstvami, zůstanou v krizové situaci jen na papíře.

\section{F. Výhled}

V závěrečných kapitolách Horton stručně podává podněty a návrhy, částečně inspirované i některými filosofy, které by mohly vést ke zlepšení současné situace, a to nejen v západních zemích. Patří mezi ně např̀:

- rozvoj solidarity a sociálního zdraví, při němž jde o celkové zdraví populace; 80

80 Horton mluví o konceptu ,jednoho zdraví“ (One Health), při němž je zřejmá sounáležitost zdraví jednotlivce a celé populace: „... solidarity ... mutual respect, mutual concern ... My health depends on your heath. Your health depends on my health. We cannot excape on another. The 
- $\quad$ rozvoj dlouhodobé bdělosti vưči epidemickým rizikům; ${ }^{81}$

- rozvoj „planetárního zdraví; 82

- $\quad$ integrace vědeckého výzkumu a klinické praxe; ${ }^{83}$

- vyvážení svobody slova s adekvátní odpovědí na infodemii;

- harmonizace sledování se svobodou a soukromím. ${ }^{84}$

Především poslední témata, totiž svoboda a ochrana soukromí, je v současném západním diskurzu o koronaviru hojně diskutované. Jak jsem již zmínil v úvodu, existuje rozšířený dojem, že úspěchu při marginalizaci viru dosahují především autoritářské země (ČLR), které na svobodu a soukromí nehledí, zatímco režimy respektující tyto hodnoty jsou neúspěšné. Horton je nicméně přesvědčen, že faktor režimu není zásadní, že např. sledování je možné uvést v soulad i s liberální společností, budou-li zachovány principy jako jsou rovnost, transparentnost, atd. ${ }^{85} \mathrm{~S}$ Hortonovým názorem se ztotožňuji, třebaže jsem si vědom, že téma soukromí a svobody vs. epidemické bezpečnosti

liberties that we prize so highy depend on the health of all of us. ... We are social being. We are political beings. Covid-19 has taught us that we are mutual beings too. ... Covid-19 will change publics: Public will no longer view disease as a pathology of the body. We will see disease as a pathology of society. People will deman stronger systems of health/social protection“ Horton (2020, s. 127), srv. také Horton (2020, s. 122) a poznámku č. 82 níže..

81 „Eternal vigilance truly is the price of freedom. We cannot afford to repeat the cycle of crisis, harm, action, complacency, neglect and subsequent vulnerability that followed SARS in 20023." (Horton 2020, s. 110).

$82, \ldots$ the threat this pandemic posed will emphasize the importance of protecting and strenghteing the health of civilizations as well as communities - what we might call our planetary health.“ ... The concept of One health: „health of humans and the health of animals are intricately connected“ Horton (2020, s. 120). Zde by bylo možné doložit výzkumy ohledně ekologických kořenů této epidemie, srv. (Latinne et al. 2020).

83 „Covid-19 will change science: Speedy integration of research into clinical practice, equity and transparency (e.g. in vaccine)..." Horton (2020, s. 122).

84 „How do we reconcile the need for greater surveillance to diminish risks of future pandemic the biopolitical disciplinary society - with a demand to protect the freedoms ... ? Does greater surveillance stand in opposition to our right to privacy?" Horton (2020, s. 108).

85 „I don't fear greater state intrusion into our lives - the panopticonization of society - provided that we insist that this intrusion is guided by some agreed principles, standards and values“ (s. 109). (Horton zde cituje Foucaultovu knihu Biopolitics). Následně Horton stručně vypočítává i morální a právní principy, které je třeba při sledování zachovat: „(1) universality and inalienability - privacy protection must be afforded by everyone, without exception; (2) indivisibility, our rights are interdependent, it is not for the state to determine which rights it will and will not guarantee; (3) equality and non-discriminatory - all human beings are equal in their dignity; (4) transparency - governments must be open about information and their decision-making“" Horton (2020, s. 109). 
je třeba zpracovat daleko podrobněji. Dle některých předběžných studií např. neexistuje korelace mezi demokratičností režimu a úmrtností. ${ }^{86}$ Dokonce bych si dovolil tvrdit opak: dobře fungující země, kde populace spolupracuje $s$ důvěryhodnými odborníky a politiky při ochraně veřejného zdraví, má výhodu oproti zemím s problémovým politickým zřízením. Autoritářské země sice mohou mít dočasné krátkodobé výhody, např. s rychlou organizací uzávěry či s dohledem (surveillance), nicméně z dlouhodobého hlediska je třeba získat k upřímné spolupráci většinu populace, což může být pro autoritářské země problémem.

Hortonovy podněty bude jistě vhodné dále přezkoumat, rozpracovat a případně $\mathrm{v}$ rámci disciplín jako je veřejné/globální zdraví, integrálně začlenit do vzdělávání zdravotníků, nejrůznějších odborníků, politiků, ale $\mathrm{v}$ neposlední řadě $\mathrm{i}$ řadových občanů. $\mathrm{V}$ některých zemích schází porozumění principům ochrany veřejného zdraví nejen politikům či řadovým občanům, ale navíc došlo i $\mathrm{k}$ selhání lékařské profese při vyhodnocení dostupné evidence; i zde bude třeba podniknout nápravu. ${ }^{87}$

Horton vyjadřuje své obavy, že současná koronakrize nepovede k hlubší reformě slabých míst západních společností a že př́ležitosti a hrozby koronakrize zůstanou ležet ladem. ${ }^{88}$ Řešení mnohých dalších globálních problémů (chudoba, hlad, klima, atd.) se zpomalí, USA se i nadále bude stahovat z mezinárodního společenství, dojde k „odmítání Č́ny“", bez níž, navzdory jakýmkoli výhradám, nelze globální problémy

86 Např. dle studie australského libertariánského think-tanku Lowy Institute: Lowy Institute (2021): Covid Performance Index [online]. Dostupný z: https://interactives.lowyinstitute.org/ features/covid-performance/.

87 Bez ohledu na sporné úzké vymezení pojmu „evidence“, které se, jak se zdá, prosadilo v hnutí tzv. „evidence-based medicine“ (srv. Fuller 2020), je zřejmé, že základem medicíny nemá být kvazi-božská autorita člověka (at’ už má sebevětší počet titulů), ale právě evidence (v širokém smyslu slova, tj. zahrnující i potenciální rizika a hrozby). Mnozí lékaři by měli i po padesáti letech vzít vážně výzvu skotského epidemiologa A. L. Cochrana: „In 1972, Professor Archie Leman Cochrane, a Scottish epidemiologist published his book Effectiveness and Efficiency: Random Reflections on Health Services (1972) where he advocated the return to the basic concepts behind evidence-based practice, first formulated by Aristotle (Fig. 10). He criticized the medical profession for much of its practices based on experience rather than evidence ... In many specialties, evidence-based guidelines are continuously being formulated by these bodies and are continuously being updated as new evidence emerges ... It is therefore only appropriate, at this point in time, to remember that evidence-based medicine is in fact a revival of a concept formulated twenty four centuries ago by the great philosopher Aristotle, father of logic." (Sallam 2010).

88 „Along with outbreaks, a recurring pattern of societal amnesia has prevailed. Each microbial challenge has been followed by a period of frenetic activity at every level, internationally and nationally but has concluded with a lapse into forgettfullnes." (Snowden 2020, předmluva k brožované verzi). 
řešit, a v neposlední řadě ztratíme schopnost být šokováni: zvykneme si na umírající lidi, nekompetenci vlád a zneužití moci. Západní společnost se bude organizovat spíše na principu strachu než spolupráce. ${ }^{89}$ Tváŕí v tvář traumatizující zkušenosti zvolíme zapomnění. ${ }^{\circ}$ Zde je třeba říct, že to, jak se dále bude situace vyvíjet, není snadné predikovat, koneckonců historii predikovat nelze, záleží i na našich rozhodnutích. Zde pouze uvádím, že obavy s Hortonem sdílím, přinejmenším pro řadu západních zemí, včetně České republiky. Na druhou stranu je povzbudivé sledovat řadu nezápadních zemí, které naopak řeší epidemii racionálně a v souladu s lidskou důstojností, včetně mnoha zemí asijských a některých afrických.

Hortonova kniha se zabývá protiepidemickou odpovědí západních zemí v první polovině roku 2020. A podobně, jak jsem již zmínil v úvodu, je metodicky zúžena na toto období i tato studie. Změnila se situace vpolovinědruhé, tedy poté, co byla Hortonova kniha publikována? Mnohé západní země sice podnikly některé kroky správným směrem, ovšem převažující strategií i nadále zůstala mitigace, se všemi dlouhodobými nevýhodami zdravotními i hospodářskými, které s sebou tato strategie nese. Rozdíl mezi úspěšnou marginalizační strategií asijských a austrooceánských zemí a neúspěšnou mitigační strategií zemí západních se v druhé polovině roku 2020 jen prohloubil. Ani na konci roku 2020 nedošlo v mnoha západních zemích k jasnému vyhlášení marginalizační strategie, navzdory vědeckému konsenzu, že se jedná o jediný zpo̊sob, jak radikálně chránit veřejné zdraví, ekonomiku i další společenské hodnoty. ${ }^{91}$

89 Horton zde cituje Lars Svendsena, patrně jako varování, totiž že strach je základní organizační princip společností. (Svendsen 2008).

90 „And I worry that we will forget - forget the facts and lessions of COVID-19, just as we forgot the facts and lessons of SARS in 2002-3. Over 300,000 deaths worldwide surely counts as a significant event. In the human story. We should at least consider whether we have an obligation to remember. ... Do we as a global community have an obligation to remember ... as a shared family? I believe we do, partly because this shared memory is what we owe to those who died and partly because we need to remind ourselves what we must do to prevent this avoidable tragedy from repeating itself.“ Zde cituje (Margalit 2002), že „a proper community of memory may help shape a nation“ (Horton, s. 126). K tématu též brilantní komentátor celé koronakrize a jeho závěrečná loňská esej „Where Year Two of the Pandemic Will Take Us As vaccines roll out, the U.S. will face a choice about what to learn and what to forget“ (Yong 2020b).

91 Změnit tuto situaci se snaží pro Evropu např. výzva Priesemann et al. (2020). Srv. taktéž zmiňované The John Snow Memorandum a dokument od The Lancet COVID-19 Commissioners (2020). V ČR think-tank a občanská Inicitiva Sníh (https://www.iniciativa-snih.cz/). 
Bezprecedentně rychlý vývoj účinných vakcín staví země světa koncem roku 2020 do mnohem lepší pozice, jak současnou epidemii řešit. Staví nás ovšem i před nové výzvy. Vakcíny proti onemocnění covid-19 jsou vzácným zdrojem, který je potřeba distribuovat v souladu s uznávanými etickými principy, především spravedlností a transparentností, a současně tak, aby byla alokace tohoto zdroje co nejefektivnější. Jednou $\mathrm{z}$ povinností státu je ochrana veřejného zdraví a sociálního a ekonomického blahobytu a program vakcinace je nedílnou součástí plnění této povinnosti. Vzniká zde tedy celá řada otázek ohledně incentiv na podporu vakcinace a prioritizace při očkování, což jsou vše otázky, které zasahují i do oblasti sociální etiky, politické filosofie a etiky veřejného zdraví. Podaří se včas zajistit náročný proces produkce a distribuce vakcín, aby se život v zemích s aktivními ložisky infekce začal opět podobat životu před epidemií? Podaří se přesvědčit lidi zavalené misinformacemi a dezinformacemi, zvyklé na politické šarvátky i uprostřed boje o život, že očkování je nezbytné?

Hortonova kniha se mnohými otázkami, např. etikou vakcinace, nezabývá. Podobně i některými dalšími důležitými tématy jako je svoboda, které jsem zmiňoval např. v předchozí sekci, se Horton zabývá jen stručně. V souvislosti s hlavní tezí je zde ovšem jedna klíčová otázka, kterou si Horton explicitně neklade, třebaže k jejímu položení text jakoby přímo vybízí, totiž Schuldfrage, tj. otázka zodpovědnosti za selhání. ${ }^{92}$ Kdo je zodpovědný za úspěch či neúspěch při ochraně zdraví obyvatel před pandemií? Společnost jako celek? Stát? Konkrétní osoby? Jedná se o zodpovědnost morální či taktéž právní? Dalších dílčích otázek, které čekají na prozkoumání v souvislosti se Schuldfrage je mnoho. I samotná Hortonova analýza rané fáze koronakrize v západních zemích bude jistě časem doplněna, upřesněna, poopravena. Přesto se domnívám, že zůstane cenným svědectvím jednoho z prvních morálních a věcných pohledů na fenomén epidemie nového koronaviru.

Doufám tedy, že tato recenzní studie je spíše jen jednou z prvních filosofických reflexí koronakrize a další budou následovat. ${ }^{93} \mathrm{Na}$ mnoha

92 Přesněji řečeno, klade si tuto otázku jen okrajově a rétoricky, aby mohl vyvrátit simplistický, dezinformační narativ, že za selhání Západu je primárně zodpovědná ČLR či WHO, srv. např. „So who was responsible for a pandemic that infected 5 milions people and killed over 300,000? China? National goevernments? WHO? Some of the anwers, I think, lie in the lessons from the last outbreak of a SARS virus in 2002-5“ Horton (2020, s. 28).

93 Hortonova kniha byla přijata příznivě, recenze, spíše informačního než polemického rázu, jsem 
místech jsem nechával promluvit autora knihy at’ už přímými citacemi v hlavním textu či v poznámkách pod čarou. I na závěr bych rád ocitoval jednu z výmluvných a výstižných pasáží Hortonovy knihy, které ukazují na potřebu po bolestných zkušenostech s pandemií nepodlehnout pokušení amnézie a naopak tomuto tématu věnovat pozornost i nadále:

„Covid-19 odhalil úžasnou křehkost našich společností, naši sdílenou zranitelnost. Odhalil naši neschopnost spolupracovat, koordinovat a jednat společně. Možná koneckonců nemůžeme ovládat přírodní svět. Možná nejsme tak dominantní, jak jsme si kdysi mysleli. Pokud naplní covid-19 lidskou existenci určitou pokorou, je možné, že budeme nakonec vstřícní vůči lekcím tohoto smrtícího viru. V opačném případě upadneme zpět do naší kultury samolibé výjimečnosti v čekání na další mor, který jistě dorazí.“94

\section{Literatura}

Alwan, N. A. et al. (2020): „Scientific consensus on the COVID-19 pandemic: we need to act now." The Lancet 396 (10260): e71-e72, 31. 10. 2020 DOI: https://doi.org/10.1016/So140-6736(20)32153-X. Úvod a český překlad „Memorandum Johna Snowa: jak na úspěšný boj s Covid-19.“ In Centrum Karla Čapka [online] v sekci Etika epidemie. Dostupné z: https://www.etikaepidemie.cz/clanky/45-memorandum-johna-snowa-jak-na-uspesny-boj-s-covid-19.

Awad, E. et al. (2018): „The Moral Machine Experiment.“ Nature (563): 59-64. Dostupný z: https://www.nature.com/articles/ s41586-018-0637-6.

zaregistroval v časopisech, jako je European Journal of Public Health, Indian Journal of Medical Ethics, Public Understanding of Science, Finantial Times, a Nature. Z obsáhlejších recenzí je třeba zmínit Knight (2020) a Hurley (2020). V době příprav tohoto článku do tisku vyšlo druhé, revidované vydání Hortonovy knihy. Toto vydání jsem zatím neměl k dispozici.“

94 „COVID-19 has revealed the astonishing fragility of our societies, our shared vulnerability. It has revealed our inability to cooperate, to coordinate and to act together. Perhaps we cannot control the natural world after all. Perhaps we are not quite as dominant as we once thought. If COVID-19 eventually imbues human beings with some humility, then possible we will, after all, be receptive to the lessons of this lethal virus. Or perhaps we will sink back into our culture of complacent exceptionalism and await the next plague that will surely arrive." Horton (2020, s. 56-57). 
Balint, J., Strosberg, M., Philpott, S., Baker, R. \& Strosberg, M., eds. (2006): Ethics and Epidemics. Emerald Group Publishing Limited, Bingley.

Battin, M. P. \& Francis, L.P. \& Jacobson, J.A. \& Smith, Ch. B. (2009) The Patient as Victim and Vector: Ethics and Infectious Disease. Oxford: Oxford University Press.

Beck, U. (2004): Riziková společnost: na cestě kjiné moderně. Sociologické nakladatelství, Praha.

Broadbent, A. (2013): Philosophy of Epidemiology. Palgrave Macmillan, London.

Buckley, Ch., Kirkpatrick, D. D., Qin, A. \& Hernández, J. C. (2020): „25 Days That Changed the World: How Covid-19 Slipped China's Grasp." The New York Times [online]. 30. 12. 2020 [cit. 30. 12. 2020]. Dostupné z: https://www.nytimes. com/2020/12/30/world/asia/china-coronavirus.html.

Correia, S., Luck, S. \& Verner, E. (2020): „Pandemics Depress the Economy, Public Health Interventions Do Not: Evidence from the 1918 Flu. " DOI: http://dx.doi.org/10.2139/ssrn.3561560.

CSARIM, CSIM. (2020): Opatření vedoucí ke snižování vnímavosti populace vůči onemocnění covid-19 (tzv. přirozená imunizace)."In Česká společnost intenzivní medicíny [online]. 13. 4. 2020 [cit. 31. 12. 2020]. Dostupné z: https://csim.cz/wp-content/uploads/2020_PP_07_CSARIM_CSIM_COVID_pasivni_imunizace_final_120420_oprava-1.pdf.

Cyranoski, D. (2020): „The biggest mystery: what it will take to trace the coronavirus source." Nature, 5. 5. 2020. Dostupný z: https://www.nature.com/articles/d41586-020-01541-z.

Černý, D., Novotný, D. \& Jedlička, P. (2020): „Jak na úspěšný boj s koronavirem: Memorandum Johna Snowa: vědecký konsensus k pandemii covid-19." Tempus medicorum 29 (12): 8-9.

Delvaux, J. \& Rajan, S. (2020): „Covid-19 \& Philosophy: Towards a Bibliography." [online]. Dostupný z: https://docs.google.com/document/d/15YkfraGX4wNRUmg3M4WHCyZjLxcbnCmLtZ-YggcKTXY/edit [cit. 30. 12. 2020]. 
Dowdle, W. R. (1998): „The principles of disease elimination and eradication." Bulletin of the World Health Organization 76 (Suppl. 2): 22-25. Dostupný z: https://www.ncbi.nlm.nih.gov/pmc/articles/ PMC2305684/.

Dzúrová, D. \& Jarolímek, J. (2020): Šíření pandemie COVID-19 např́č geografickými i sociálními hranicemi: dokážeme mu čelit? Geografie 125 (1): 1-20. DOI: https://doi.org/10.37040/geografie2020125010001.

Evanega, S., Lynas, M., Adams, J. \& Smolenyak, K. (2020): „Coronavirus misinformation: quantifying sources and themes in the COVID-19 ,infodemic'." (Preprint). Dostupný z: https://www.uncommonthought.com/mtblog/wp-content/uploads/2020/12/Evanega-et-al-Coronavirus-misinformation-submitted_07_23_20-1.pdf.

Fassine, D. (2018): Life. A Critical User's Manual. Polity Press, Cambridge, UK, Medford, MA.

Fidler, D. (2004): SARS, Governance and the Globalization od Disease. Palgrave Macmillan, Basingstoke.

Fuller, J. (2020): „Modely versus evidence.“ In Centrum Karla Čapka [online]. Článek převzat z Boston Review, 20. 5. 2020, český překlad Martin Zach. [cit. 31. 12. 2020]. Dostupný z: https://www. etikaepidemie.cz/clanky/46-modely-versus-evidence.

Gans, J. (2020): The Pandemic Information Gap: The Brutal Economics of COVID-19. MIT Press, Cambridge, MA.

Gelfand, M., Jackson, J. C., Pan, X., Nau, D., Pieper, D., Denison, E., Dagher, M., Van Lange, P., Chiu, Ch. \& Wang, M. (2021): „The relationship between cultural tightness-looseness and COVID-19 cases and deaths: a global Analysis." The Lancet Planetary Health 5 (3). DOI: https://doi.org/10.1016/S2542-5196(20)30301-6. Green, M. S., Swartz, T., Mayshar, E., Lev, B., Leventhal, A., Slater, P. E. \& Shemer, J. (2002): „When is an epidemic an epidemic?“ The Israel Medical Association Journal 4 (1): 3-6.

Holub, P. (2020): Koronavirus: Falešný poplach. Echo media, Praha. Horák, O. (2020): „Filozof o korone: Reagujeme len na momentálne riziko, Európe chýba dlhodobý plán.“ Rozhovor s D. D. Novotným. 
Deník N [online]. 7. 11. 2020. [cit 8. 11. 2020]. Dostupný z: https://dennikn.sk/2125708/filozof-o-korone-reagujeme-len-na-momentalne-riziko-europe-chyba-dlhodoby-plan/.

Horton, R. (2003): Second Opinion: doctors, diseases and decisions in modern medicine. Granta Books, London.

Horton, R. (2020): The Covid-19 Catastrophe: What's Gone Wrong and How to Stop it Happening Again. Polity, Cambridge.

Honigsbaum, M. (2020): The Pandemic Century. A History of Global Contagion from the Spanish Flu to Covid-19. Penguin, Cambridge, MA.

Huntington, S. (2001): Střet civilizací, boj kultur a proměna světového řádu. Rybka publishers, Praha.

Hurley, Z. (2020): „Review of Richard Horton (2020): The Covid-19 Catastrophe: What's Gone Wrong and How to Stop it Happening Again." Postdigital Science and Education 2 (3): 1015-1019, 27. 7. 2020. DOI: 10.1007/s42438-020-00171-y.

Christakis, N. (2020): Apollo's Arrow: The Profound and Enduring Impact of Coronavirus on the Way We Live. Little Brown Spark, New York.

Jedlička, P. (2021): „Personální okénko: Vladimír Černý, architekt ,českého řešení، "In Facebook - Petr Jedlička [online]. 27. 2. 2021 [cit. 2. 3. 2021]. Dostupné z: https://www.facebook.com/login/?next=https\%3A\%2F\%2Fwww.facebook.com\%2Fpetrjedlicka100\%2Fposts\%2F10225845478423207.

Jones, K., Patel, N., Levy, M., Storeygard, A., Balk, D., Gittleman J. L. \& Daszak, P. (2008): „Global trends in emerging infectious diseases." Nature 451: 990-993. DOI: https://doi.org/10.1038/natureo6536.

Kerles, M. (2020a): „Jsme svědky experimentu s lidmi. Jeho dosah si mnozí nedovedou ani představit, rríká Novotný." Info.cz [online]. Rozhovor s D. D. Novotným. 18. 03. 2020. Dostupný z: https://www.info.cz/cesko/jsme-svedky-experimentu-s-lidmi-jeho-dosah-si-mnozi-nedovedou-ani-predstavit-rika-novotny-44614. html.

Kerles, M. (202ob): „Druhou vlnu covidu si vyrábíme sami, ř́ká filozof Novotný.“ Info.cz [online]. Rozhovor s D. D. Novotným. 24. 07. 
2020. Dostupný z: https://www.info.cz/zpravodajstvi/cesko/covid19-rozhovor-novotny.

Kerles, M. (2020c): „Západ v boji s koronavirem zvolil horší taktiku. A zbytečně obětoval tisíce životů, říká filozof Novotný." Info. cz [online]. Rozhovor s D. D. Novotným. 21. 10. 2020. Dostupný z: https://www.info.cz/zpravodajstvi/cesko/zapad-v-boji-s-koronavirem-zvolil-horsi-taktiku-a-zbytecne-obetoval-tisice-zivotu-rika-filozof-novotny.

Knobler, S., Mahmoud, A., Lemon, S., Mack, A., Sivitz, L. \& Oberholtzer, K., eds. (2004): Learning from SARS: Preparing for the Next Disease Outbreak. National Academic Press, Washington. Knight, S. (2020): „The Lancet editor's wild ride through the coronavirus pandemic." The New Yorker [online]. 27. 6. 2020 [cit. 8. 11. 2020]. Dostupný z: https://www.newyorker.com/news/letter-from-the-uk/the-lancet-editors-wild-ride-through-the-coronavirus-pandemic.

Koubský, P. (2020): „Rok covidu očima Petra Koubského: Můžeme si lehnout a rozplakat se. Lepší je ale vstát, číst a pochopit.“ Deník $N$ [online]. 22. 12. 2020 [cit. 25. 12. 2020]. Dostupný z: https://denikn.cz/521923/muzeme-si-lehnout-a-rozplakat-se-lepsi-je-ale-vstat-cist-a-pochopit-rok-covidu-ocima-petra-koubskeho/.

Křepelka, F. (2020): „Právo pandemie covidu-19: náčrt celkového obrazu. " Časopis zdravotnického práva a bioetiky 10 (2): 1-70.

Kulveit, J. (2021): „Debata v Česku je i obětí vědeckých omylů. A o joaniditech." [online] [cit. 27. 2. 2020]. Dostupný z: https://boundedlyrational.substack.com/p/debata-v-esku-je-i-obt-vdeckch-omyl.

Kucharski, A. (2020): The Rules of Contagion. Why Things Spread and Why They Stop. Baci Books, New York.

Latinne, A., Hu, B., Olival, K. J. et al. (2020): „Origin and cross-species transmission of bat coronaviruses in China." Nature Communications 11. DOI: https://doi.org/10.1038/s41467-020-17687-3. Lennox, J. (2020): Where Is God in a Coronavirus World? Epsom, UK, Good Book Company. 
Löckenhoff, C., Lee, D., Buckner, K., Moreira, R., Martinez, S. \& Sun, M. (2015): „Cross-Cultural Differences in Attitudes About Aging: Moving Beyond the East-West Dichotomy." In Successful Aging: Asian Perspectives, eds. Cheng, S-T., Chi, I., Fung, H., Li, L., \& Woo, J., Springer, Dordrecht, s. 321-337. DOI: 10.1007/97894-017-9331-5_19.

MacKenzie, D. (2020): Covid-19: The Pandemic that Never Should Have Happened, and How to Stop the Next One. Hachette Books, New York.

Mallapaty, S., Maxmen, A. \& Callaway, E. (2021): „Major stones unturned': COVID origin search must continue after WHO report, say scientists.“ Nature 590: 371-372. DOI: https://doi. org/10.1038/d41586-021-00375-7.

Margalit, A. (2002): The Ethics of Memory. Harvard University Press, Cambridge, MA.

Martin, P. M. \& Martin-Granel, E. (2006): „2,500-year evolution of the term epidemic." Emerging Infectious Diseases 12 (6): 976-980. DOI: doi:10.3201/eid1206.051263.

Miller, J. ed. (2020): The Coronavirus: Human, Social and Political Implications. (C) 2020, Palgrave MacMillan, Singapore.

Ord, T. (2020): The Precipice: Existential Risk and the Future of Humanity. Hachette Books, New York.

Philips, N. (2021): „The coronavirus is here to stay - here's what that means." Nature 590: 382-384, 16. 2. 2021. DOI:

https://doi.org/10.1038/d41586-021-00396-2.

Priesemann, V. et al. (2021): „Calling for pan-European commitment for rapid and sustained reduction in SARS-CoV-2 infections." The lancet 397 (10269): 92-93, 9. 1. 2021, publikováno 18. 12. 2020. DOI: https://doi.org/10.1016/So140-6736(20)32625-8.

Quammen, D. (2012): Spillover: Animal infections and the next human pandemic. W. W. Norton \& Company, New York.

Rabadán, R. (2020): Understanding Coronavirus. Cambridge University Press, Cambridge.

Rothman, K. J., Greenland, S. \& Lash, T. L. (2008): Modern Epidemiology. Third Edition. Lippincott Williams \& Wilkins, Philadelphia. 
Sallam, H. N. (2010): „Aristotle, godfather of evidence-based medicine." Facts, views \& vision in ObGyn 2 (1): 11-19.

Saracci, R. (2010): Epidemiology: A Very Short Introduction. Oxford University Press, Oxford.

Schwartz, M. C., ed. (2020): The Ethics of Pandemics. Broadview Press, Peterborough, ON.

Simiao, Ch. et al. (2020): „Fangcan shelter hospitals: a novel concept for responding to public health emergencies." The Lancet 395 (10232): 1305-1314. 18. 4. 2020, elektronicky 2. 4 2020. DOI: 10.1016/So140-6736(20)30919-3.

Snowden, F. M. (2019): Epidemics and Societies: From the Black Death to the Present. Yale University Press, New Haven; brožované vydání s novou předmluvou Yale University Press, New Haven, 2020.

Svendsen, L. (2008): A Philosophy of Fear. Reaktion Books, London.

Šejvl, M., Agha, P., Sobek, T., Kokešová, J. \& Černý, D. (2020): Vítězove a poraženi': Práuni' a etické problémy současne' koronakrize. Ústav státu a práva AV ČR, Praha.

The Lancet COVID-19 Commissioners (2020): „Lancet COVID-19 Commission Statement on the occasion of the 75th session of the UN General Assembly." The Lancet 396 (10257): 1102-1124, 10.10. 2020, elektronicky 14. 8. 2020. Dostupný z: https://www.thelancet.com/journals/lancet/article/PIISo140-6736(20)31927-9/fulltext.

Walter-Toews, D. (2020): On Pandemics: Deadly Diseases from Bubonic Plague to Coronavirus New Edition. Greystone Books, Vacouver.

Wayne, M. L. \& Bolker, B. B. (2015): Infection Disease: A Very Short Introduction. OUP, Oxford.

WHO (2020): Report of the WHO-China Joint Mission on Coronavirus Disease 2019 (COVID-19) In World Health Organization. [online]. 16.-24. 2. 2020. Dostupný z: https://www.who.int/docs/ default-source/coronaviruse/who-china-joint-mission-on-covid-19-final-report.pdf.

Yong, E. (2020a): „Why the Coronavirus Is So Confusing: A guide to making sense of a problem that is now too big for any one per- 
son to fully comprehend." The Atlantic [online]. 29. 4. 2020. Dostupný z: https://www.theatlantic.com/health/archive/2020/04/ pandemic-confusing-uncertainty/610819/.

Yong, E. (2020b): „Where Year Two of the Pandemic Will Take Us As vaccines roll out, the U.S. will face a choice about what to learn and what to forget." The Atlantic [online]. 29. 12. 2020. Dostupný z: https://www.theatlantic.com/health/archive/2020/12/pandemic-year-two/617528/.

Žižek, S. (2020): Pandemic! Covid-19 Shakes the World. OR Books, New York.

\section{Abstract}

\section{The Covid-19 Catastrophe: On the book of Richard Horton}

In this review study, I reflect on Richard Horton's book and his thesis that Western countries failed in their response to the current epidemic in the first half of 2020, with a few exceptions. In the five sections of the paper, after an initial modification of Horton's thesis (A), I discuss briefly: suppression approach in China (B), mitigation approach in the West (C), the SARS epidemic as the key global public health event (D), the causes of West failure (epistemic, political, ethical, cultural, etc.) (E), and final envoi (F).

Key word: epidemic ethics, covid-19, public health, health policy, West

Novotný, D. D. (2020): „Covid-19 katastrofa: Nad knihou Richarda Hortona.“ Filosofie dnes 12 (2): 88-127. Dostupné z www.filosofiednes.ff.uhk.cz 